\title{
Glial Cells Transform Glucose to Alanine, which Fuels the Neurons in the Honeybee Retina
}

\author{
M. Tsacopoulos,' A.-L. Veuthey, ${ }^{1}$ S. G. Saravelos,' P. Perrottet,' and G. Tsoupras ${ }^{2}$ \\ 'Experimental Ophthalmology Laboratory, University of Geneva, School of Medicine, and ${ }^{2}$ Hewlett-Packard (Switzerland), \\ 1211 Geneva 4, Switzerland
}

The retina of honeybee drone is a nervous tissue with a crystal-like structure in which glial cells and photoreceptor neurons constitute two distinct metabolic compartments. The phosphorylation of glucose and its subsequent incorporation into glycogen occur in glia, whereas $\mathrm{O}_{2}$ consumption $\left(\mathrm{QO}_{2}\right)$ occurs in the photoreceptors. Experimental evidence showed that glia phosphorylate glucose and supply the photoreceptors with metabolic substrates. We aimed to identify these transferred substrates. Using ion-exchange and reversedphase HPLC and gas chromatography-mass spectrometry, we demonstrated that more than $50 \%$ of ${ }^{14} \mathrm{C}(\mathrm{U})$-glucose entering the glia is transformed to alanine by transamination of pyruvate with glutamate. In the absence of extracellular glucose, glycogen is used to make alanine; thus, its pool size in isolated retinas is maintained stable or even increased. Our model proposes that the formation of alanine occurs in the glia, thereby maintaining the redox potential of this cell and contributing to $\mathrm{NH}_{3}$ homeostasis. Alanine is released into the extracellular space and is then transported into photoreceptors using an $\mathrm{Na}^{+}$-dependent transport system. Purified suspensions of photoreceptors have similar alanine aminotransferase activity as glial cells and transform ${ }^{14} \mathrm{C}$-alanine to glutamate, aspartate, and $\mathrm{CO}_{2}$. Therefore, the alanine entering photoreceptors is transaminated to pyruvate, which in turn enters the Krebs cycle. Proline also supplies the Krebs cycle by making glutamate and, in turn, the intermediate $\alpha$-ketoglutarate. Light stimulation caused a $\mathbf{2 0 0} \%$ increase of $\mathrm{QO}_{2}$ and a $\mathbf{5 0} \%$ decrease of proline and of glutamate. Also, the production of ${ }^{14} \mathrm{CO}_{2}$ from ${ }^{14} \mathrm{C}$-proline was increased. The use of these amino acids would sustain about half of the light-induced $\Delta \mathrm{QO}_{2}$, the other half being sustained by glycogen via alanine formation. The use of proline meets a necessary anaplerotic function in the Krebs cycle, but implies high $\mathrm{NH}_{3}$ production. The results showed that alanine formation fixes $\mathrm{NH}_{3}$ at a rate exceeding glutamine formation. This is consistent with the rise of a glial pool of alanine upon photostimulation. In conclusion, the results strongly support a nutritive function for glia.

Received Mar. 31, 1993; revised July 19, 1993; accepted Aug. 19, 1993

This work was supported by the Swiss National Science Foundation 31-30038.90, the G. Kernen Foundation, and the de Reuter Foundation. We are grateful to Drs. J. A. Coles, M. Prentki, M. Yudkoff, and S. Poitry for helpful comments on the manuscript. We thank Dr. S. Poitry for his contribution in electrical recordings and Dr. M. Koth for help with liquid chromatography and measurements of enzymes.

Correspondence should be addressed to Marcos Tsacopoulos, Experimental Ophthalmology Laboratory, Centre Médical Universilaire, 1, rue Michel-Servet, 1211 Geneva 4, Switzerland.

Copyright (C) 1994 Society for Neuroscience $0270-6474 / 94 / 141339-13 \$ 05.00 / 0$
IKey words: honeybee retina, glial cells, photoreceptor neuron, glycogen, glucose fate, pyruvate amination, alanine, alanine aminotransferase, proline, glutamate]

A number of diverse functions have been attributed to glial cells, most of which contribute to the satisfactory functioning of the neurons (for review, see Barres, 1991). We have provided evidence supporting the hypothesis that glial cells transform metabolic substrates from the blood and supply neurons with metabolites (Tsacopoulos et al., 1988). This is a modified version of Golgi's original hypothesis made popular by Kuffler and Nicholls (1976). Indeed, Golgi (1903) considered the possibility that glial cells "serve to distribute nutrient substances" to the neurons, but in the formulation of his idea there is no notion of molecular transformation of substrates. A related but distinct notion is that substrate is stored in the glia, which can release it to the neurons when necessary. Thus, histological observations showed that glial cells contain considerable amounts of glycogen and that glycogen can be almost depleted by 1 min of ischemia or hypoxia (Lowry et al., 1964; Lajtha et al., 1981; for citations, see Sorg and Magistretti, 1992). However, the nature of the substrate used is unknown and it remains to be proven that the substrate is not entirely consumed by the glial cells themselves. An interesting hypothesis of metabolic interaction is the so-called "glutamate-glutamine cycle," proposing that astrocytes transform glutamate to glutamine, which fuels the neurons (for review, see Hertz et al., 1983). However, the strongest support of this hypothesis is based on work performed on cultured astrocytes (see Erecinska and Silver, 1990), and its generality from the functional point of view has been recently questioned (Yudkoff et al., 1992).

We have subjected the nutritive glial function hypothesis to experimental investigation using the honeybee drone retina as a model. It is a nervous tissue with a crystal-like structure comprising only one type of neuron, the photoreceptor, which directly responds to light stimulation, and one type of glial cell, the outer pigment cell (Perrelet, 1970). The separation of metabolic functions (oxidative metabolism and carbohydrate metabolism) between these cells is exceptionally complete. Photoreceptor cells are devoid of glycogen and contain a large number of mitochondria all arranged at the periphery of the cells in close apposition to the plasma membrane (Tsacopoulos et al., 1987). In contrast, glial cells are filled with glycogen and contain very few mitochondria (see Fig. $8 A$ in this article and Fig. 1 in Dimitracos and Tsacopoulos, 1985). In retinal slices superfused for several hours with oxygenated Ringer solution without metabolic substrate, photoreceptors consume large quantities of $\mathrm{O}_{2}$ $\left(\mathrm{QO}_{2}\right)$ in the dark and during photostimulation (Tsacopoulos et 
al., 1981; Tsacopoulos and Poitry, 1982). Maintenance of this $\mathrm{QO}_{2}$ requires the oxidation of large amounts of carbohydrate, which were found to be stored in the form of glycogen in the glial cells (Evêquoz et al., 1983; Tsacopoulos et al., 1983, 1987; Evêquoz-Mercier and Tsacopoulos, 1991). In addition, glial cells are the principal cellular site for the phosphorylation of glucose to glucose-6P (Tsacopoulos et al,, 1988; Brazitikos and Tsacopoulos, 1991), in accordance with enzymatic measurements demonstrating predominant hexokinase activity in the glial cells (Veuthey et al., 1994). Therefore, it is most probable that glucose is not the substrate used by photoreceptors and that glial cells transform glucose or glycogen to glucose-6P, which is further metabolized to substrates for subsequent transfer to photoreceptors (Tsacopoulos et al., 1988; Evêquoz-Mercier and Tsacopoulos, 1991). We aimed to identify these transferred substrates. In this report we demonstrate that glucose is transformed to alanine, probably in glial cells, and we propose that alanine and proline fuel the mitochondria of the photoreceptors.

\section{Materials and Methods}

\section{Preparation of retinal slices}

The experiments were done on $\sim 250-\mu$ m-thick slices of the retina of the honeybee drone Apis mellifera prepared as already described (Tsacopoulos and Poitry, 1982; Tsacopoulos et al., 1987; Brazitikos and Tsacopoulos, 1991).

\section{Incubation with labeled substrates}

Freshly cut retinal slices were transferred in a plastic microincubator (see Fig. 1 in Evêquoz-Mercier and Tsacopoulos, 1991) and incubated $60 \mathrm{~min}$ in darkness in Ringer solution (in mM: $270 \mathrm{NaCl}, 10 \mathrm{KCl}, 10$ $\mathrm{MgCl}_{2}, 1.6 \mathrm{CaCl}_{2}$, and 10 HEPES buffer at $\mathrm{pH} 7.4$ ) containing one of the following radioactive substrates (Amersham, UK): about $350 \mu \mathrm{M}$ glucose $\left(100 \mu \mathrm{Ci} / \mathrm{ml}\right.$ of D-U- ${ }^{14} \mathrm{C}$-glucose; $\left.286.9 \mathrm{mCi} / \mathrm{mmol}\right) ; 75 \mu \mathrm{M}$ or $1.25 \mathrm{~mm}$ alanine $\left(\mathrm{L}-\mathrm{U}-{ }^{14} \mathrm{C}\right.$-alanine; $\left.160 \mathrm{mCi} / \mathrm{mmol}\right) ; 375 \mu \mathrm{M}$ proline $(\mathrm{L}-$ U-14 $\mathrm{C}$-proline; $266 \mathrm{mCi} / \mathrm{mmol}) ; 187 \mu \mathrm{M}$ glutamate $\left(\mathrm{L}-\mathrm{U}-{ }^{14} \mathrm{C}\right.$-glutamate; $266 \mathrm{mCi} / \mathrm{mmol})$; or $31 \mu \mathrm{M}$ pyruvate $\left(1-{ }^{14} \mathrm{C}\right.$-pyruvate; $\left.32 \mathrm{mCi} / \mathrm{mmol}\right)$. During incubation the solution was stirred by a jet of pure moist oxygen ensuring good oxygenation throughout the retina as checked with an $\mathrm{O}_{2}$-sensitive microelectrode (see Tsacopoulos et al., 1981). At the end of incubation, slices were rinsed for $1 \mathrm{~min}$ in substrate-free Ringer solution to remove labeled substances adhering to the tissue surface. Then retinal slices were either directly frozen in a chilled propaneisopentane mixture or further incubated following two protocols: (1) in experiments where incubation medium was analyzed, retinal slices were further incubated for $30 \mathrm{~min}$ in the same conditions but with substratefree Ringer solution; (2) retinal slices were placed in the superfusion chamber described by Tsacopoulos and Poitry (1982) and superfused with fully oxygenated substrate-free Ringer solution for different periods of time. The calculation of the concentrations of various compounds was made as described previously (Tsacopoulos et al., 1988; Brazitikos and Tsacopoulos, 1991) by taking the wet weight of the retina to be $4.4 \times$ dry weight.

\section{Preparation of slices for chromatographic analysis}

Frozen retinal slices were lyophilized, dissected from the optic lobe at the level of the basal membrane (see Fig. 3 in Tsacopoulos et al., 1987; Fig. 2 in Brazitikos and Tsacopoulos, 1991), weighed ( $120 \mu \mathrm{g}$ per retina), and homogenized by sonication in $100 \mu \mathrm{l}$ of $\mathrm{H}_{2} \mathrm{O}$. The homogenate was then deproteinized $\left(100^{\circ} \mathrm{C}\right.$ for $\left.5 \mathrm{~min}\right)$ and filtered (Millipore Ultrafree-MC, $0.1 \mu \mathrm{m}$ ).

\section{${ }^{14} \mathrm{C}$-alanine uptake and incubations under light stimulation}

Slices were first fixed with low-melting-point wax (Eicosan, Fluka, Switzerland) on a hemicylindrical support made from stainless steel (radius, $3.5 \mathrm{~mm}$; thickness, $2.5 \mathrm{~mm}$ ) in such a way that the retinas were exposed to Ringer solution from both faces and then transferred to the superfusion chamber (see Fig. 2 in Tsacopoulos et al., 1981; Fig. 2 in Tsacopoulos and Poitry, 1982). The superfused retina was dark adapted for $30 \mathrm{~min}$ and then tested for good functioning by measuring lightinduced $\Delta \mathrm{QO}_{2}$ and the receptor potential with microelectrodes as de- scribed in previous detailed accounts (Tsacopoulos and Poitry, 1982; Tsacopoulos et al., 1983, 1987). Poorly responding retinas were discarded. Following the test, the retina attached to the support was transferrcd to the loading well made from plexiglass and bathed in $80 \mu \mathrm{l}$ of fully oxygenated Ringer solution carrying ${ }^{14} \mathrm{C}$-alanine. All manipulations were performed under $614 \mathrm{~nm}$ light that has no detectable electrical or metabolic effects on the drone retina (see also Jones and Tsacopoulos, 1987), but allows good visual control. The slices were bathed for various periods of time (maximum of $60 \mathrm{~min}$ ) in the dark or under repetitive flashes of white light attenuated by $1 \log$ unit. Due to the fact that the retina was exposed to the $\mathrm{O}_{2}$ flux from both faces there was no development of anoxic cores during photostimulation (see Tsacopoulos et al., 1981; Tsacopoulos and Poitry, 1982). At the end of a given experimental period the slice was withdrawn from the well under $614 \mathrm{~nm}$ light, washed in oxygenated Ringer solution for $1 \mathrm{~min}$, and frozen. The frozen retina was processed as described above for chromatographic analysis. In some experiments the $\mathrm{Na}^{+}$in the bathing solution was replaced by choline.

\section{${ }^{14} \mathrm{CO}_{2}$ measurements}

The ${ }^{14} \mathrm{CO}_{2}$ production from $\mathrm{U}-{ }^{14} \mathrm{C}$-glucose, $\mathrm{U}-{ }^{14} \mathrm{C}$-alanine, and $\mathrm{U}-{ }^{14} \mathrm{C}$ proline was measured in a novel microincubator made of glass. The slice fixed on the hemicylindrical support was immersed in $200 \mu \mathrm{l}$ of Ringer solution carrying the labeled substrate in which $100 \% \mathrm{O}_{2}$ was microbubbled. The outlet was connected to a glass tube containing Hyamine-impregnated filters $(1 \mathrm{ml})$. The ${ }^{14} \mathrm{CO}_{2}$ collected on the $\mathrm{Hy}$ amine filter was measured by scintillation counting in $1 \mathrm{ml}$ of methanol and $5 \mathrm{ml}$ of liquid scintillation cocktail (Ultima Gold, Packard Instrument Co.).

\section{Measurements of oxygen consumption}

The $\mathrm{QO}_{2}$ in the dark and during repetitive or continuous light stimulation was measured with $\mathrm{O}_{2}$-sensitive microelectrodes using the quantitative method described in great detail in previous reports (Tsacopoulos et al., 1981; Tsacopoulos and Poitry, 1982).

\section{High-pressure liquid chromatography (HPLC) analysis}

Carbohydrate analysis. We used a modified version of our method described in Evêquoz-Mercier and Tsacopoulos (1991): in this study two ion-exchange columns (Aminex HPX 87H, Bio-Rad Laboratories, Richmond, CA) in series were used at $50^{\circ} \mathrm{C}$ and at a flow rate of 0.5 $\mathrm{ml} / \mathrm{min}$. The elution solvent was $5 \mathrm{mM}$ of $\mathrm{H}_{2} \mathrm{SO}_{4}$. A refractive index detector was used (Erma ERC-7515A, Erma Inc., Tokyo, Japan) on line with a fraction collector (Helifrac 2212, Pharmacia LKB, Uppsala, Sweden). The method for enzymatic identification of the trehalose peak has been described in a previous report (Evêquoz-Mercier and Tsacopoulos, 1991). In addition, the identity of glucose-6P peaks was confirmed as follows. The fraction corresponding to the peak having the same elution time as standard glucose- $6 \mathrm{P}$ was collected, using $\mathrm{H}_{2} \mathrm{O}$ as mobile phase, frozen, and lyophilized. The residue was dissolved in $110 \mu \mathrm{l}$ of $\mathrm{Na}$ acetate buffer (pH 6.57) containing $6 \mathrm{mg}$ of glucose- 6 phosphatase (Sig$\mathrm{ma} 0.083 \mathrm{unit} / \mathrm{mg}$ prot) and incubated for $20 \mathrm{~min}$ at $37^{\circ} \mathrm{C}$. The reaction was stopped by heating at $100^{\circ} \mathrm{C}$ for $5 \mathrm{~min}$ and the deproteinized sample was analyzed again by HPLC. Under these conditions the peak of ${ }^{14} \mathrm{C}$ glucose-6P was reduced by more than $80 \%$ and the peak of ${ }^{14} \mathrm{C}$-glucose was increased proportionally. The peak collected as described previously was also used to determine the total retinal content of glucose-6P by measuring the NADPH product in the presence of glucose-6P dehydrogenase, using a fluorometric method according to Lowry and Passonneau (1972). Identification of the pyruvate peak was checked by altering its elution time by changing the $\mathrm{pH}$ of the elution solvent.

Amino acid analysis. We used three chromatographic methods for amino acid analysis of the homogenates. In the first method we used an ion-exchange column (Aminex HPX-87C; Bio-Rad Laboratories, Richmond, $\mathrm{CA}$ ) at $65^{\circ} \mathrm{C}$ and at constant flow rate of $0.6 \mathrm{ml} / \mathrm{min}$ (linear pump Irica $\Sigma 871$, Irica Instruments Inc., Kyoto, Japan) with $5 \mathrm{~mm}$ of $\mathrm{Ca}\left(\mathrm{NO}_{3}\right)_{2}(\mathrm{pH} 5.5)$. This is a modified version of the method described by Favre et al. (1990), and does not require derivatization, which would have been impaired by the high concentration of ions in the bathing solution (see below). It was also convenient to use $\mathrm{H}_{2} \mathrm{O}$ as the mobile phase for further identification in the gas chromatography-mass spectrometry (GC-MS) system (see below). In the second method we used a reverse-phase column (Spherisorb $3 \mu \mathrm{m}$, ODS2, HPLC Technology, Macclesfield, Cheshire, UK) at room temperature and at a flow rate of 
$1.5 \mathrm{ml} / \mathrm{min}$ (pump 420 from Kontron Instruments AG, Zurich, Switzerland) and a Chrom-A-Scope UV detector (BarSpec, Rehovot, Israel) on line with a fraction collector. The derivatization of amino acids was made with phenylisothiocyanate (PITC) as described recently by Fierabracci et al. (1991). As an internal standard we used homocysteine $(250 \mu \mathrm{M})$. The elution solvent was $3 \%$ acetonitrile in $0.1 \mathrm{M}$ ammonium acetate. These isocratic conditions were sufficient to allow a good separation of glutamate, alanine, $\beta$-alanine, and proline, four amino acids of major interest in this study. Further identification of alanine and proline was achieved using combined liquid chromatography-mass spectrometry (LC-MS): a Hewlett-Packard 1090 liquid chromatograph was coupled to an HP 5989 mass spectrometer equipped with a thermospray interface. The data system was the computer HP 9000 Serial 425t (Hewlett-Packard, Palo Alto, CA). The experiment was done as follows: several lyophilized retinal slices were microdissected, weighed, and pooled together. The homogenate was chromatographed using an ion-exchange column and $\mathrm{H}_{2} \mathrm{O}$ as mobile phase. The putative fractions corrcsponding to alanine and proline peaks were collected and lyophilized. The residue was dissolved in $\mathrm{H}_{2} \mathrm{O}$ and injected in the HPLC column (RP- 18, $125 \times 4.0 \mathrm{~mm}, 5 \mu \mathrm{m}$ ) of the LC-MS system. The elution was carried out using a gradient program from $0.1 \mathrm{~m}$ ammonium acetate solution (adjusted to $\mathrm{pH} 4.5$ with glacial acetic acid) to $30 \%$ methanol in $0.1 \mathrm{M}$ ammonium acetate solution in $10 \mathrm{~min}$ at a flow rate of $1 \mathrm{ml}$ / $\mathrm{min}$. The mass spectrometric conditions were as follows: stem temperature was held at $100^{\circ} \mathrm{C}$, tip temperature at $260^{\circ} \mathrm{C}$, source temperature $270^{\circ} \mathrm{C}$, and filament electron energy $950 \mathrm{eV}$. Under these conditions the mass spectral data of the isolated compounds from the retinal homogenates were in agreement with those obtained for standard compounds.

The third method was also based on reversed phase chromatography with precolumn derivatization with ortho-phthaldehyde and fluorescence detection (Turnell and Cooper, 1982), using HP 1090 liquid chromatography system (Hewlett-Packard, Palo Alto, CA). For the detection of proline, dansyl derivatization was used. This third method was used to confirm the concentration of amino acids obtained with the UV method.

\section{Detection of ${ }^{15} \mathrm{~N}$ enrichment of amino acids}

${ }^{15} \mathrm{~N}$ isotopic abundance in amino acids was determined by a GC-MS system (Hewlett-Packard, Palo Alto, CA). Slices of drone retina $300 \mu \mathrm{m}$ thick were incubated individually in Ringer solution carrying $10 \mathrm{~mm}$ $\mathrm{L}^{-15} \mathrm{~N}$-glutamate $(95 \%$ purity, Cambridge Isotope Laboratories, Woburn, MA) for $60 \mathrm{~min}$. Each corresponding homogenate was analyzed by ion-exchange HPLC amino acid analysis as described above and all peaks of interest were collected individually; the fractions corresponding to the same peak were pooled. The pooled eluates were lyophilized and the trimethylsilyl derivatives of the putative amino acids formed with $N, O$-bis(trimethylsilyl)trifluoroacetamide (Regisil RC-2, Supelco) were analyzed by GC-MS. Similar derivatization methods were described by Erecinska et al. (1988). Determination of ${ }^{15} \mathrm{~N}$ enrichment was carried out by monitoring the characteristic fragment ions $\left(\mathrm{M}-\mathrm{CH}_{3}\right)^{+}$and $[\mathrm{M}-$ COOSi $\left.\left(\mathrm{CH}_{3}\right)_{3}\right]^{+}$, both containing the amino group of the molecule, in the selective ion monitoring mode. The ratios of ions $M+1 / M$ are shown in Table 2. An HP 5890A gas chromatograph was coupled to an HP 5989 mass spectrometer operating in the electron impact mode. A capillary column HP-1 ( $25 \mathrm{~m}, 0.22 \mu \mathrm{m}$ i.d., and $0.32-\mu \mathrm{m}$-thick film) was used with $\mathrm{He}$ as carrier. Under these conditions electron impact spectra and retention times of isolated amino acids from homogenates were identical to those of the reference compounds.

\section{Cellular dissociation of the retina}

A 400-500- $\mu$ m-thick slice was made, and while it was bathed in icecold oxygenated Ringer solution most of the brain tissue was removed using a combination of suction with a polished micropipette and microdissection with sharpened fine forceps. Then the retina, still tightly attached to the cornea, was transferred to the glass microincubator described above and bathed at room temperature for $20-30 \mathrm{~min}$ in 300 $\mu \mathrm{l}$ of continuously oxygenated Ringer solution containing $3 \mathrm{mg} / \mathrm{ml}$ of pronase (Calbiochem). This treatment completely detached the cornea, which was removed. Then the retinal tissue was carefully transferred to an Eppendorf tube and washed with fresh ice-cold Ringer solution for $10 \mathrm{~min}$. After that it was exposed to $400 \mu \mathrm{l}$ of $0-\mathrm{Ca}^{2+} / 0-\mathrm{Mg}^{2+}$ Ringer solution containing $0.3 \%$ bovinc scrum albumin (BS $\Lambda$ ) (no EGTA was used) and triturated very slowly 10 times using a fire-polished Pasteur pipette. The time of exposure to this solution did not exceed $3 \mathrm{~min}$.
The volume of the solution was made up to $1 \mathrm{ml}$ by adding normal Ringer solution containing $0.3 \% \mathrm{BSA}$ and trituration pursued very gently 10 more times. Care was taken to withdraw inside the Pasteur pipette as much volume as possible, avoiding, however, air bubbles. This procedure was optimum in our hands for the yield of large numbers of visually intact clusters of photoreceptors (see Fig. $7 A$ ). This procedure allows the isolation of groups of several glial cells attached together at the corneal extremity. It was possible to obtain individual glial cells by more extensive and vigorous trituration. However, such trituration broke almost all photoreceptors. Following trituration the suspension of cells was spread on a BSA-coated coverslip mounted on an inverted microscope and the cells were collected with fire-polished micropipettes of the type shown in Figure $7 G$, connected to a specially designed hydraulic system equipped with precision microdrives, allowing very delicate and precise suction of the cells. The tip diameter of the micropipettes for the collection of the clusters of photoreceptors was $25 \mu \mathrm{m}$ and for glial cells $50 \mu \mathrm{m}$. In a given suspension only photoreceptors or only glial cells were collected. The collected cells were extruded in a drop of $10 \mu \mathrm{l}$ of Tris- $\mathrm{HCl}$ buffer solution $(10 \mathrm{~mm}$ ) containing $0.25 \mathrm{M}$ sucrose and $1 \mathrm{~mm}$ EDTA ( $\mathrm{pH}$ 7.4). Several drops were pooled and frozen in liquid $\mathrm{N}_{2}$ until enzymatic analysis. Despitc many attempts, we failed to separate the two cell types using a continuous Percoll gradient similar to that used to isolate glial Müller cells from mammalian retinas (Poitry-Yamate and Tsacopoulos, 1992). One reason for the failure could be that the photoreceptors and glial cells of the drone retina are the same length.

\section{Biochemical measurements}

The kinetic determination of alanine aminotransferase (ALAT) was performed enzymatically using a standard kit of reactants (Enzyline, Bio-Mérieux, France) and a fully automatic, computer-assisted spectrophotometer (Hitachi 717, Japan). The AIAT activity was measured in homogenates of intact retinas, of mixed suspensions of dissociated cells, isolated photoreceptors, and glial cells and subcellular fractions. The method of subccllular fractionation will be described in a forthcoming report (Veuthey et al., 1994). Milliunits of enzymatic activity $(\mathrm{mU})$ are defined as nanomoles of product formed per minute.

Glycogen content was measured using a slightly modified version (see Evêquoz et al., 1983) of the fluorometric micromethod described by Nahorski and Rogers (1972).

Protein concentration was measured using the bicinchoninic acid protein assay kit, Sigma procedure TPRO-562 (Smith et al., 1985).

\section{Electrical recordings}

The current recording shown in Figure $7 G$ was obtained as follows. Cell suspension prepared as described above and bathed in Kinger solution of the following composition: $\mathrm{NaCl} 229 \mathrm{~mm} ; \mathrm{KCl}, 10 \mathrm{~mm} ; \mathrm{MgCl}_{2}, 10$ mM; $\mathrm{CaCl}, 1.6 \mathrm{~mm}$; L-aspartic acid (monosodium), $10 \mathrm{~mm}$; L-glutamic acid (monosodium), $10 \mathrm{~mm}$; alanine, $20 \mathrm{~mm}$; proline, $20 \mathrm{~mm}$; glutamine, $2 \mathrm{~mm}$; and HEPES, $10 \mathrm{~mm}$ ( $\mathrm{pH} \mathrm{7.43).} \mathrm{An} \mathrm{aliquot} \mathrm{of} \mathrm{this} \mathrm{suspension}$ was then placed in the recording chamber on the microscope stage. The field in the chamber containing the cells was viewed using an infrared television system attached to the microscope as described in Fein and Tsacopoulos (1988) and one cluster of photoreceptors was selected for recording. The selected cluster was sucked into a tight-fitting glass recording pipette that was connected to the input of a conventional patchclamp amplifier (List EPC7, Germany). For more details, see Cornwall et al. (1983). Light from a dual beam optical bench was focused onto the preparation from below by a microscope objective, which replaces the microscope condenser (see Fein and Tsacopoulos, 1988). The light spot normally used for the stimulation of small cells (vertebrate rods) illuminated only part of the cluster.

\section{Electron microscopy}

The electron micrograph shown in Figure $8 \mathrm{~A}$ was prepared by Dr. A. Perrelet as described in Perrelet (1970). The electron micrographs shown in Figure $8, B$ and $C$, were prepared by Dr. O. Baumann at the Institut of Zoology, University of Regensburg, Germany. The photoreceptors were isolated as described above and fixed in $4 \%$ paraformaldehyde and $3.5 \%$ glutaraldehyde in $0.1 \mathrm{~m} \mathrm{Na}$-cacodylate $(\mathrm{pH} \mathrm{7.4)}$ for $3 \mathrm{hr}$ at room temperature. The preparation was postfixed for $1 \mathrm{hr}$ at $4^{\circ} \mathrm{C}$ by adding $1 \%$ tannic acid, and then washed three times for $5 \mathrm{~min}$ in $0.1 \mathrm{M} \mathrm{Na}-$ cacodylate $(\mathrm{pH} 7.4)$ and exposed to $1 \% \mathrm{O}_{3} \mathrm{O}_{4}$ in $0.1 \mathrm{M}$ Na-cacodylate for $2 \mathrm{hr}$ at room temperature. The specimens were stained en bloc with $2 \%$ aqueous uranyl acetate, dehydrated in a graded ethanol series, and 

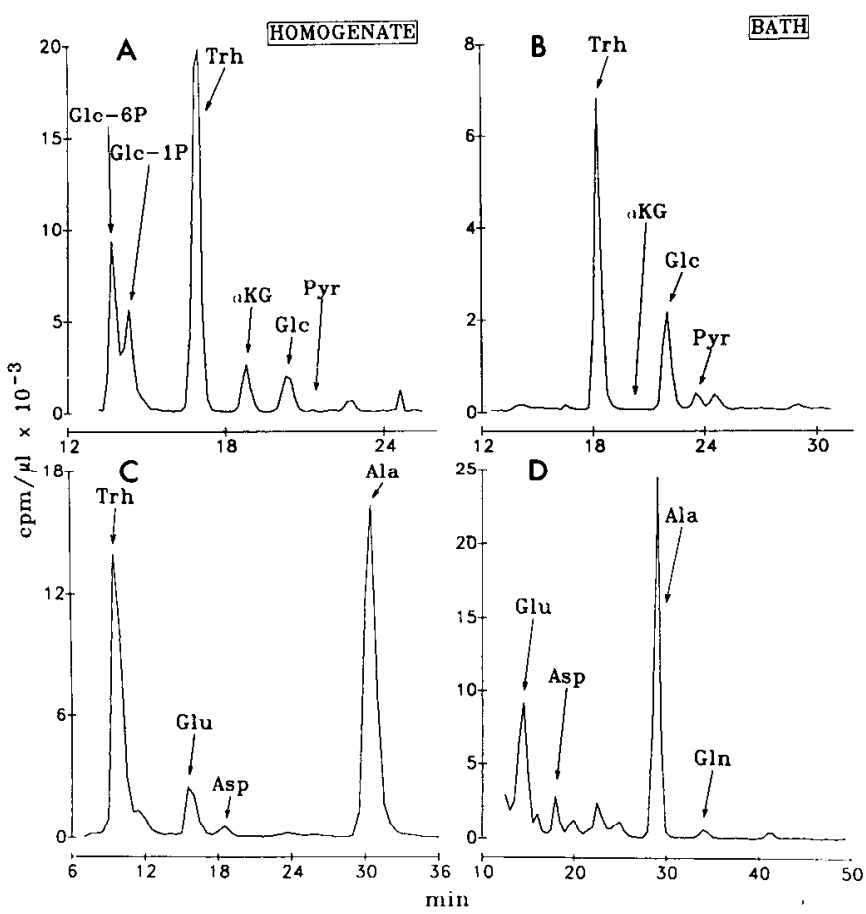

Figure 1. Fate of $\mathrm{U}-{ }^{14} \mathrm{C}$-glucose in the drone retina after $60 \mathrm{~min}$ of incubation. $A$ and $C$ are HPLC chromatograms of retinal homogenates, and $B$ and $D$ of bathing solutions analyzed after $30 \mathrm{~min}$ of washing in substrate-free Ringer solution. The chromatograms $A$ and $B$ were made with an ion-exchange column of the $\mathrm{H}^{+}$form, while $C$ and $D$ were made with the $\mathrm{Ca}^{2+}$ form. In $D$ the beginning of the chromatogram was omitted (elution of trehalose and glucose) to show better the amino acids of interest. $T r h$, trehalose

embedded in Epon. Ultrathin sections were poststained with uranyl acetate and lead citrate, and observed in a Zeiss EM 10 electron microscope (Baumann, 1992).

\section{Results}

The fate of $U-{ }^{14} \mathrm{C}$-glucose in retinal slices

Carbohydrate metabolites. Following incubation for $60 \mathrm{~min}$ in the presence of $\mathrm{U}-{ }^{14} \mathrm{C}-\mathrm{glucose}$, retinal slices were analyzed by

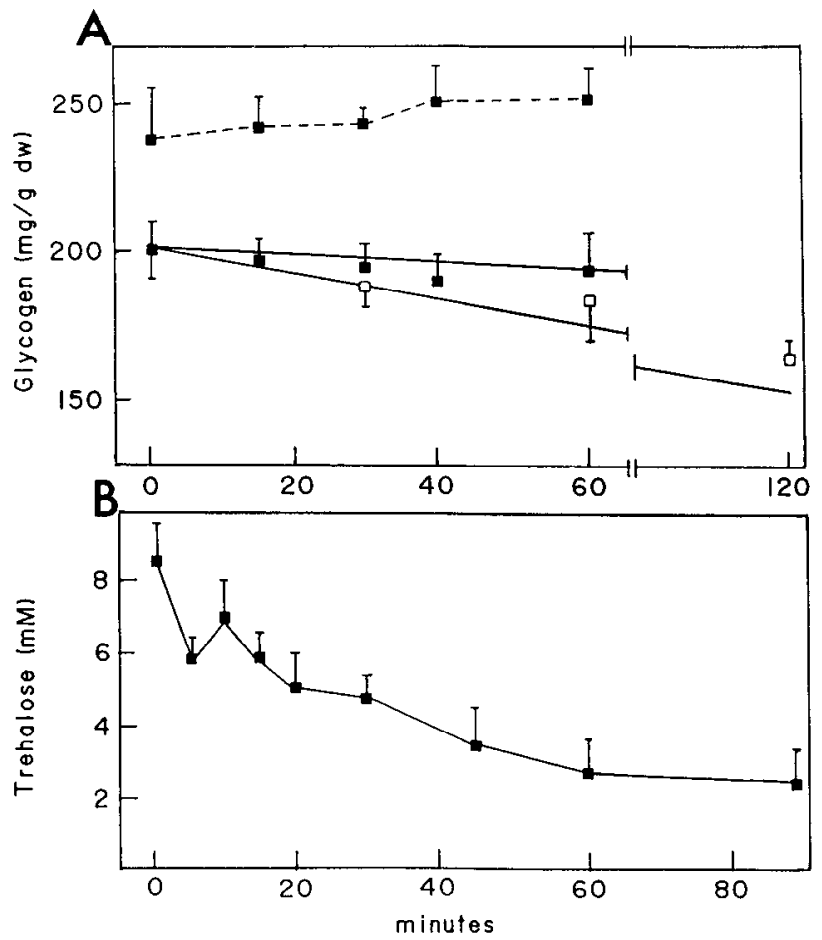

Figure 2. A, Effect of light stimulation on glial glycogen content. Retinas were superfused with oxygenated Ringer solution either substratefree (middle and lower traces) or containing $30 \mathrm{~mm}$ of glucose (upper trace) in order to mimic the glucose concentration in the hemolymph of living bees. $\square$, darkness; $\square$, light stimulation. The error bars are SEM. Each point is the average value from $6-10$ retinas. The $t w o$ straight lines, middle and lower, were calculated taking the $\mathrm{QO}_{2}$ values measured in other preparations and assuming that glycogen was the only metabolic fuel. $B$, Trehalose content decreased as a function of time of superfusion in darkness with substrate-free Kinger solution. Each point is the average value from 10 retinas. Light stimulation had no significant effect on this decrease (not shown).

ion-exchange HPLC to determine the labeled intracellular carbohydrate metabolites. Besides $\mathrm{U}_{-14}{ }^{14} \mathrm{C}$-glucose, the principal peaks in the chromatogram coincided with those of ${ }^{14} \mathrm{C}$-glucose- $6 \mathrm{P}$ $\left({ }^{14} \mathrm{C}\right.$-glucose-1 P), ${ }^{14} \mathrm{C}$-trehalose, and ${ }^{14} \mathrm{C}$ - $\alpha$-ketoglutarate (Fig. $1 \mathrm{~A}$ ).

Table 1. Amino acids in the retina

\begin{tabular}{|c|c|c|c|c|c|c|c|c|}
\hline Conditions & Ala & Pro & Glu & Gln & Asp & Tau & $\beta \mathrm{Ala}$ & Arg \\
\hline Fresh, not superfused & $\begin{array}{l}11.1 \\
( \pm 0.57) \\
N=5\end{array}$ & $\begin{array}{l}43.1 \\
( \pm 1.55) \\
N=5\end{array}$ & $\begin{array}{l}27.7 \\
( \pm 1.0) \\
N=5\end{array}$ & $\begin{array}{l}1.97 \\
( \pm 0.27) \\
N=5\end{array}$ & $\begin{array}{l}32.4 \\
( \pm 4.6) \\
N=5\end{array}$ & $\begin{array}{l}42.2 \\
( \pm 2.1) \\
N=5\end{array}$ & $\begin{array}{l}12.9 \\
N=1\end{array}$ & ND \\
\hline 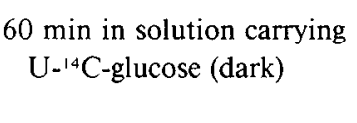 & $\begin{array}{l}12.4 \\
( \pm 0.57) \\
N=12\end{array}$ & $\begin{array}{l}26.1 \\
( \pm 1.37) \\
N=10\end{array}$ & $\begin{array}{l}12.7 \\
( \pm 0.38) \\
N=10\end{array}$ & $\begin{array}{l}2.2 \\
( \pm 0.20) \\
N=10\end{array}$ & $\begin{array}{l}11.0 \\
( \pm 0.74) \\
N=10\end{array}$ & $\begin{array}{l}26.4 \\
( \pm 1.46) \\
N=11)\end{array}$ & $\begin{array}{c}4.66 \\
( \pm 0.33) \\
N=11\end{array}$ & $\begin{array}{l}2.62 \\
( \pm 0.15) \\
N=13\end{array}$ \\
\hline $\begin{array}{l}60 \text { min in solution carrying } \\
\mathrm{U}-{ }^{14} \mathrm{C} \text {-glucose (light) }\end{array}$ & $\begin{array}{l}20.7 \\
( \pm 0.85) \\
N=5\end{array}$ & $\begin{array}{l}10.9 \\
( \pm 0.40) \\
N=5\end{array}$ & $\begin{array}{l}3.2 \\
( \pm 0.60) \\
N=5\end{array}$ & $\begin{array}{l}3.9 \\
( \pm 0.47) \\
N=5\end{array}$ & $\begin{array}{l}11.1 \\
( \pm 1.5) \\
N=5\end{array}$ & $\begin{array}{l}26.8 \\
( \pm 2.9) \\
N=5\end{array}$ & $\begin{array}{c}5.1 \\
( \pm 0.04) \\
N=5\end{array}$ & $\begin{array}{l}3.5 \\
( \pm 0.52) \\
N=5\end{array}$ \\
\hline $\begin{array}{l}60 \mathrm{~min} \text { in solution carrying } \\
{ }^{14} \mathrm{C} \text {-proline (dark) }\end{array}$ & $\begin{array}{l}13.9 \\
( \pm 0.55) \\
N=4\end{array}$ & $\begin{array}{l}32.5 \\
( \pm 3.9) \\
N=4\end{array}$ & $\begin{array}{l}13.0 \\
( \pm 1.73) \\
N=4\end{array}$ & $\begin{array}{l}1.95 \\
( \pm 0.6) \\
N=4\end{array}$ & $\begin{array}{l}12.6 \\
( \pm 1.96) \\
N=4\end{array}$ & $\begin{array}{l}28.3 \\
( \pm 2.7) \\
N=4\end{array}$ & $\begin{array}{l}4.4 \\
( \pm 0.72) \\
N=4\end{array}$ & $\begin{array}{l}2.5 \\
( \pm 0.30) \\
N=4\end{array}$ \\
\hline $\begin{array}{l}135 \text { min superfusion in } \\
\text { substrate-free Ringer } \\
\text { solution }\end{array}$ & $\begin{array}{l}27.5 \\
( \pm 2.0) \\
N=4\end{array}$ & $\begin{array}{l}1.84 \\
( \pm 0.83) \\
N=4\end{array}$ & $\begin{array}{l}5.3 \\
( \pm 0.72) \\
N=4\end{array}$ & $\begin{array}{l}2.2 \\
( \pm 0.14) \\
N=4\end{array}$ & ND & ND & ND & ND \\
\hline
\end{tabular}




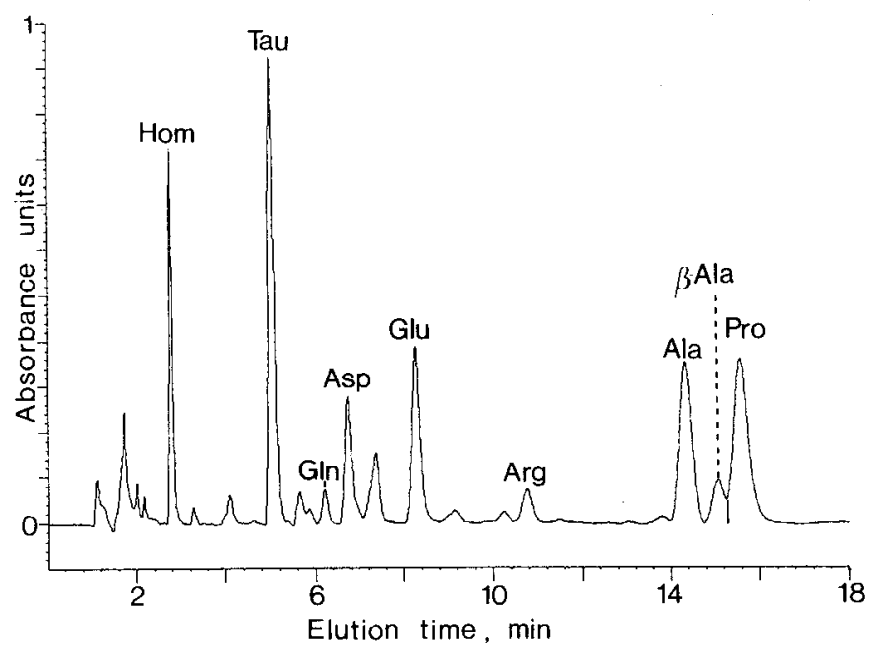

Figure 3. Analysis of total amino acid of a retinal homogenate using reversed-phase HPLC and precolumn derivatization with PITC. The retinal slice was $300 \mu \mathrm{m}$ thick (160 $\mu \mathrm{g}$ dry weight).

The identities of glucose-6P and trehalose were confirmed as described in Materials and Methods. In previous experiments we have shown that under identical experimental conditions only $1-2 \%$ of total radioactivity was incorporated in glycogen (Tsacopoulos et al., 1988; Evêquoz-Mercier and Tsacopoulos, 1991). Trehalose was by far the most important labeled carbohydrate, carrying $30 \%$ of the total radioactivity incorporated in the retina. The concentration of this disaccharide was measured in freshly dissected retinas and found to be variable (2.5$17 \mathrm{~mm}$ ). When the retinas were bathed in Ringer solution carrying $10 \mathrm{~mm}$ trehalose, the internal concentration of trehalose equilibrated with the external one (not shown). The presence of $10 \mathrm{~mm}$ trehalose in the incubation medium did not inhibit the synthesis of trehalose from $\mathrm{U}-{ }^{14} \mathrm{C}-$ glucose. After $1 \mathrm{hr}, 6-7 \%$ of the intracellular trehalose pool was labeled. In the absence of added metabolic substrate, the intracellular concentration of trehalose dropped to approximately $2.5 \mathrm{~mm}$ after $2 \mathrm{hr}$ of superfusion (Fig. 2B). Since the glycogen pool size slightly decreased after $2 \mathrm{hr}$ in substrate-free Ringer solution (Fig. $2 A$ ), it appears that part of the intracellular trehalose was used for the maintenance of that pool. Labeled trehalose was also released from the cells in the incubation medium (Fig. $1 B$ ).

Another major labeled molecule is glucose-6P, which was not entirely separated from the putative glucose-1P (Fig. 1A). Extrapolation of the ${ }^{14} \mathrm{C}$-glucose- $6 \mathrm{P}$ peak to the base line gave an average value of radioactivity under the peak of $20,836 \mathrm{cpm} /$ $\mu$ retina ( $\pm 2315 \mathrm{SEM}, N=3$ ), or the equivalent of $37 \mu \mathrm{M}$ labeled glucose-6P. The total intracellular concentration of glucose-6P in the superfused retina was $62 \mu \mathrm{M}( \pm 4.96 \mathrm{SEM}, N=12)$, so it follows that about $60 \%$ was labeled. This high specific radioactivity is consistent with a molecule that is intensively metabolized and not stored. The $\mathrm{H}$ ' ion-exchange column separated the carbohydrate metabolites but was inadequate for the complete analysis of the fate of $\mathrm{U}-{ }^{14} \mathrm{C}$-glucose because $55 \%$ of the labeled material was not eluted.

Amino acids. Using the $\mathrm{Ca}^{2+}$ ion-exchange column, more than $90 \%$ of the labeled material in the homogenate was eluted from the column after $40 \mathrm{~min}$. About $50 \%$ of the total radioactivity was found in alanine (Fig. $1 C^{C}$ ). The identification and purity of the alanine peak was confirmed unambiguously by mass spec-

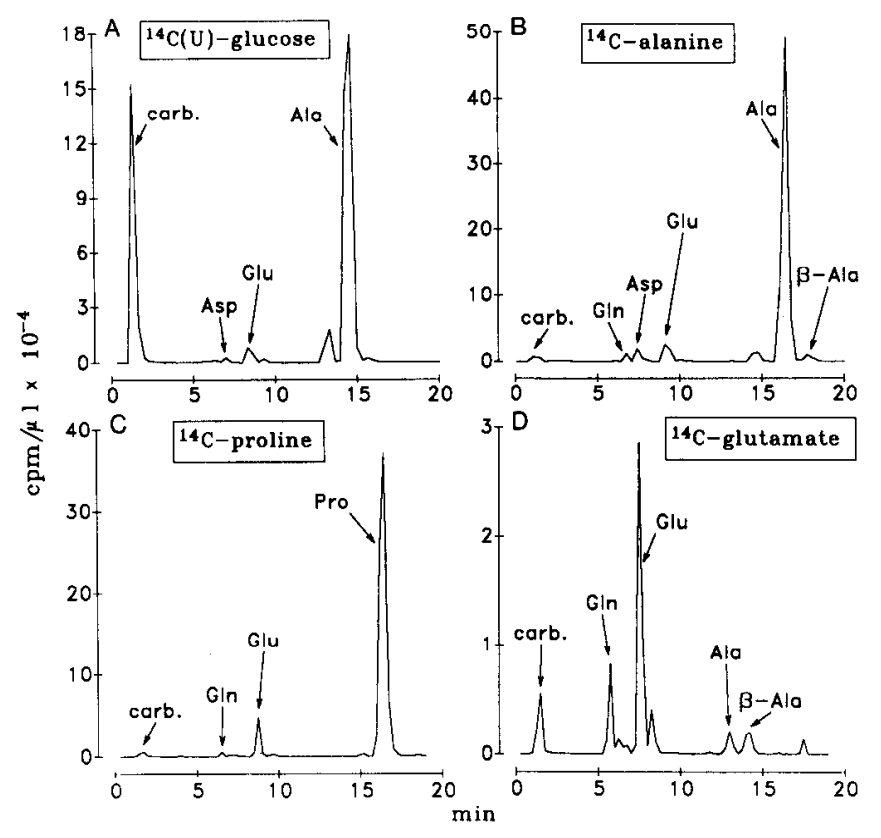

Figure 4. Analysis of labeled amino acids of retinal homogenates using reversed-phase column HPLC and precolumn derivatization with PITC for the study of metabolism of the indicated labeled substrates following 60 min of incubation. Fraction collection, at the outlet of the UV detector (see Fig. 3), was made every $15 \mathrm{sec}$. Each collection was counted individually and the lines were traced by computer. The nonderivatized carbohydrates are eluted at the front of the chromatogram. In $D$ the carbohydrate peak was collected and analyzed with $\mathrm{H}^{+}$ion-exchange column. Several Krebs cycle intermediates were eluted (see Results).

trometry as described in Materials and Methods. Hence, the major radiolabeled product of $\mathrm{U}^{14} \mathrm{C}$-glucose is alanine. After 60 min of incubation in Ringer solution carrying $330 \mu \mathrm{M}$ of $\mathrm{U}-{ }^{14} \mathrm{C}$-glucose as sole substrate, the retina had accumulated the equivalent of $1.16 \mathrm{~mm}{ }^{14} \mathrm{C}$-alanine $( \pm 0.04 \mathrm{SEM}, N=9)$. Reverse-phase chromatography allowed excellent separation and sensitivity for the measurement of the concentrations of the various amino acids found in the retina (Fig. 3). The measured values are listed in Table 1. We estimate that $10.8 \%( \pm 0.8, N$ $=9$ ) of the intracellular alanine was labeled after 60 min of exposure to $\mathrm{U}^{14} \mathrm{C}$-glucose. Other labeled amino acids found with this chromatographic method were mainly glutamate but also aspartate and glutamine (Figs. $1 C, 4 A)$. Only $0.5 \%( \pm 0.02 \%$ SEM, $N=8$ ) of total glutamate (see Table 1) was labeled from $\mathrm{U}-{ }^{14} \mathrm{C}$-glucose. The correlation of the chromatograms of Figure 3 and Figure $4 A$ made from the same sample using reversephase HPLC showed that proline, taurine, and arginine were not labeled from $\mathrm{U}-{ }^{14} \mathrm{C}$-glucose. In addition, it is noteworthy that about $7 \%$ of the radioactivity was collected in the form of ${ }^{14} \mathrm{CO}_{2}$, corresponding to the production of $33 \mathrm{nmol}$ of ${ }^{14} \mathrm{CO}_{2}$ ( $\mathrm{ml}$ of retina $)^{-1} \cdot \mathrm{min}^{-1}( \pm 2.8 \mathrm{SEM}, N=9)$.

Classically alanine is considered to be formed from glucose by transamination of pyruvate. Experiments were carried out under conditions where glycolysis and therefore the formation of pyruvate is inhibited by $3 \mathrm{~mm}$ iodoacetate (IAA). Chromatographic analysis of homogenates of retinas incubated with $\mathrm{U}-{ }^{14} \mathrm{C}$-glucose and exposed to IAA for $45 \mathrm{~min}$ (a period necessary to reduce light-induced $\Delta \mathrm{QO}_{2}$ by more than $90 \%$; see Tsacopoulos et al., 1987; Brazitikos and Tsacopoulos, 1991) showed that IAA suppressed the formation of ${ }^{14} \mathrm{C}$-alanine from 
Figure 5. The effect of IAA on the biosynthesis of ${ }^{14} \mathrm{C}$-alanine from ${ }^{14} \mathrm{C}$-glucose. The continuous line is the control and the dotted line corresponds to the chromatogram made from a retinal homogenate exposed for $45 \mathrm{~min}$ to $3 \mathrm{~mm}$ of IAA. $B$ shows that the biosynthesis of ${ }^{14} \mathrm{C}$-alanine was preserved in the presence of IAA with ${ }^{14} \mathrm{C}$-pyruvate as a substrate. In the bathing solutions, the specific radioactivity of pyruvate $(B)$ was approximately $1 / 10$ th that of glucose $(A)$. The peak marked with a question mark in $B$ was not identified.

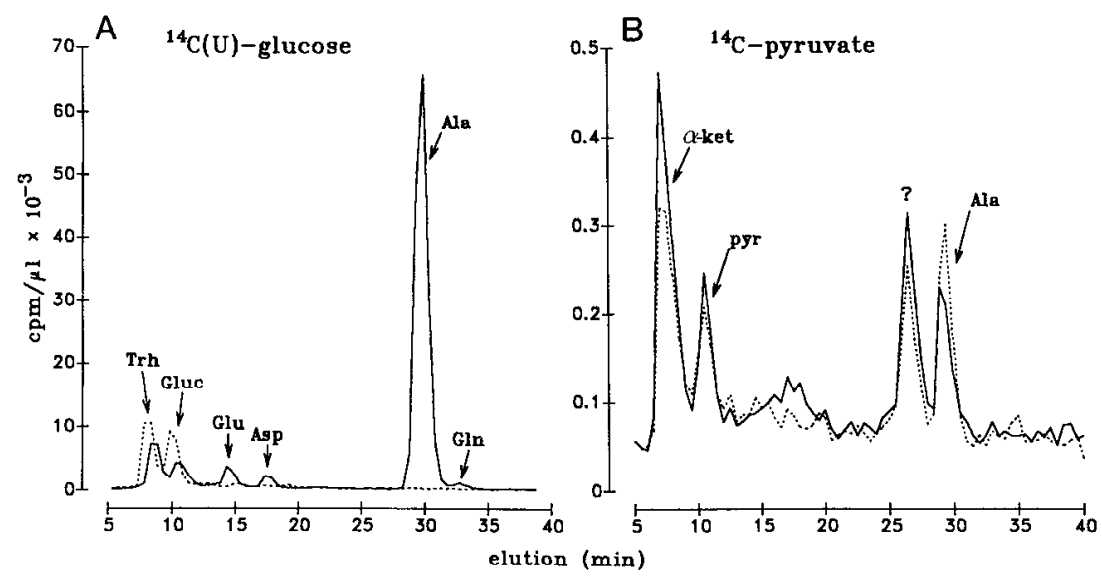

${ }^{14} \mathrm{C}$-glucose (Fig. $5 \mathrm{~A}$ ) and reduced the concentration of alanine by $53.5 \%$ (mean of three experiments). The biochemical effects of IAA are reported in detail in a forthcoming report (S. G. Saravelos and M. Tsacopoulos, unpublished observations); notice, however, in the chromatogram of Figure $5 \mathrm{~A}$ the higher level of ${ }^{14} \mathrm{C}$-glucose and ${ }^{14} \mathrm{C}$-trehalose, which is consistent with the inhibition of the phosphorylation of glucose previously observed (Brazitikos and Tsacopoulos, 1991; Poitry-Yamate and Tsacopoulos, 1992). The formation of ${ }^{14} \mathrm{C}$-alanine was preserved when the labeled carbohydrate in the superfusate was ${ }^{14} \mathrm{C}$-pyruvate (Fig. $5 B$ ), indicating that ALAT was active despite the presence of IAA. Consistent with this interpretation, when the retinas were superfused with pyruvate $(5 \mathrm{mM})$, IAA did not reduce alanine (about $11 \mathrm{~mm}$ ).

\section{Chromatographic analysis of the bathing fluid}

When the bathing solution is not renewed, as in the experiments reported in this section, a molecule released in the extracellular space and not taken up by other cells should accumulate in the bath. Following loading with $\mathrm{U}-{ }^{14} \mathrm{C}$-glucose for $60 \mathrm{~min}$, slices were transferred to the glass microincubator containing $200 \mu \mathrm{l}$ of Ringer solution continuously oxygenated and bathed in the dark for $30 \mathrm{~min}$. Subsequently, the bathing solution was subjected to HPLC analysis for ${ }^{14} \mathrm{C}$-labeled carbohydrates and amino acids. We found ${ }^{14} \mathrm{C}$-trehalose and ${ }^{14} \mathrm{C}$-glucose but, as expected for phosphorylated compounds, no ${ }^{14} \mathrm{C}-$ glucose- $6 \mathrm{P}$ or ${ }^{14} \mathrm{C}$-glucose- $1 \mathrm{P}$ was released (Fig. $1 B$ ). Further, no ${ }^{14} \mathrm{C}-\alpha$-ketoglutarate was detected (Fig. $1 B$ ). All labeled amino acids found in the retina were also released and accumulated in the medium (Fig. 1D): ${ }^{14} \mathrm{C}$-alanine was by far predominant, representing $69.0 \%$ $( \pm 2.3 \mathrm{SEM}, N=6$ ) of the labeled amino acids in the medium, followed by glutamate $(20.0 \% \pm 2.4 \mathrm{SEM}, N=6)$. After $30 \mathrm{~min}$ the retina had released the equivalent of $216 \mu \mathrm{mol}$ of ${ }^{14} \mathrm{C}$-labeled alanine and $56 \mu \mathrm{mol}$ of ${ }^{14} \mathrm{C}$-labeled glutamate per liter of retina in the extracellular space.

\section{Transmembrane transport of ${ }^{14} \mathrm{C}$-alanine and utilization by mitochondria}

Figure 6 shows an approximately linear accumulation of $U-{ }^{14} \mathrm{C}$ alanine in the retina as a function of time. After 60 min the retina had accumulated about $384 \mu \mathrm{M}$ of $U-{ }^{14} \mathrm{C}$-alanine, showing that alanine entered the cells against a concentration gradient. As shown in Figure 6, at least $50 \%$ of this transport is $\mathrm{Na}^{+}$ dependent. During superfusion with $0-\mathrm{Na}^{+}$Ringer solution, $\mathrm{Na}^{+}$ in the photoreceptors falls rapidly and remains lower than extracellular $\mathrm{Na}^{+}$for at least tens of minutes. The glial cells, which initially have a relatively high $\mathrm{Na}^{+}$, slowly lose $\mathrm{Na}^{+}$and it is presumably for this reason that $\mathrm{Na}^{+}$in the extracellular clefts does not fall below about $1 \mathrm{~mm}$ (Coles and Orkand, 1985). Hence, in $0-\mathrm{Na}^{+}$Ringer solution, $\mathrm{Na}^{+}$-coupled transport should be effective into the photoreceptors but not the glial cells.

Chromatographic analysis of homogenates of retinas that had been incubated in Ringer solution carrying ${ }^{14} \mathrm{C}$-alanine showed that there was formation of labeled $\beta$-alanine, glutamate, aspartate, glutamine, possibly pyruvate, and $\alpha$-ketoglutarate (Fig. 4B).

We examined also whether alanine could provide a substrate for oxidative metabolism. A $60 \mathrm{~min}$ incubation of retinal slices in oxygenated Ringer solution carrying $1.25 \mathrm{~mm}$ of $\mathrm{U}-{ }^{14} \mathrm{C}$-alanine yielded $170 \mathrm{nmol}( \pm 5.33 \mathrm{SEM}, N=9)$ of ${ }^{14} \mathrm{CO}_{2}(\mathrm{ml}$ of retina $)^{-1} \cdot \mathrm{min}^{-1}$ in the dark. Presumably alanine is converted to pyruvate, which, since it enters the Krebs cycle, does not accumulate. Hence, the drone retina can take up and consume alanine.

\section{Alanine biosynthesis}

We have documented that the major part of $\mathrm{U}^{1{ }^{4}} \mathrm{C}$-glucose is converted to ${ }^{14} \mathrm{C}$-alanine. The next question concerned the identification of the amino acid used in the transamination process of pyruvate to alanine. Figure $4 D$ shows that ${ }^{14} \mathrm{C}$-glutamate was transported into the cells and transformed to ${ }^{14} \mathrm{C}$-glutamine, ${ }^{14} \mathrm{C}$ alanine, and ${ }^{14} \mathrm{C}-\beta$-alanine. The compounds eluted in the front of the chromatogram are Krebs cycle intermediates including $\alpha$-ketoglutarate, malate, and succinate. Slices were incubated in medium containing ${ }^{15} \mathrm{~N}$-glutamate $(10 \mathrm{~mm})$ for $60 \mathrm{~min}$ and then processed as described in Materials and Methods for GC-MS analysis after derivatization. The objective was to monitor relative changes in the ratio of ${ }^{15} \mathrm{~N} /{ }^{14} \mathrm{~N}$ in various isolated amino acids. As shown in Table 2, mass spectrometry showed an isotopic enrichment $\left({ }^{15} \mathrm{~N} /{ }^{14} \mathrm{~N}\right)$ of alanine of about $8 \%$ due to the transamination reaction of ${ }^{15} \mathrm{~N}$-glutamate (representing $20 \%$ of the total concentration) with pyruvate. Proline showed no significant enrichment $(0.6 \%)$, whereas aspartate was not enriched under these conditions (not shown) (for calculation, see Rosenblatt et al., 1992). The fact that the ratio of labeling in intracellular glutamate/extracellular glutamate was not $\sim 1$ means that the system had not reached a steady state after $60 \mathrm{~min}$. We expect that following longer incubations with ${ }^{15} \mathrm{~N}$-glutamate the 


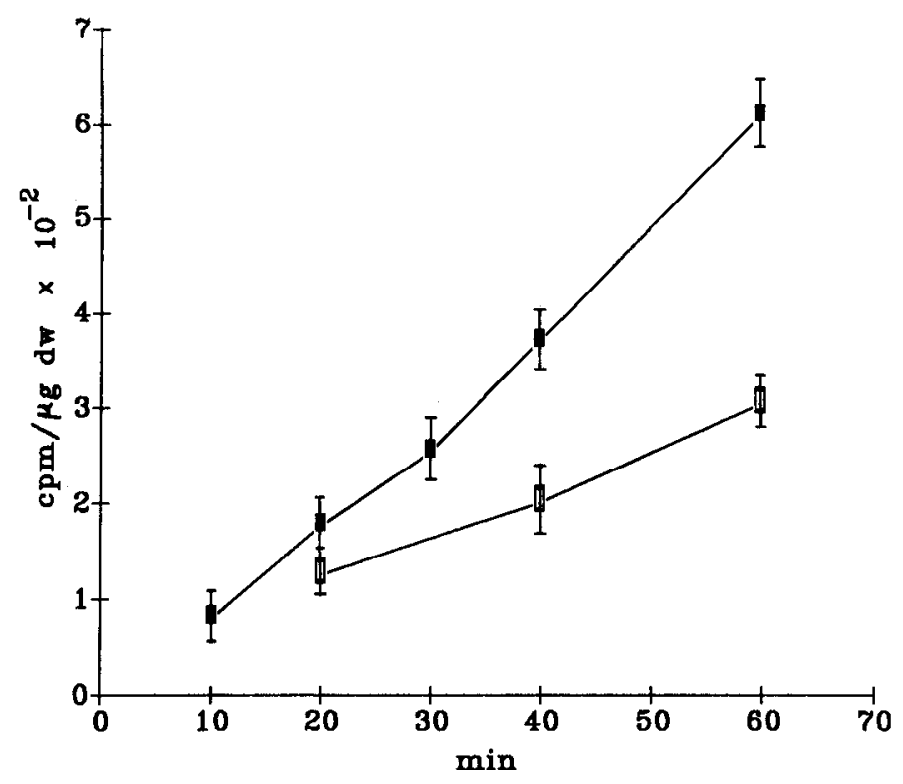

Figure 6. Effect of Na' replacement by choline' on the uptake and accumulation of ${ }^{14} \mathrm{C}$-alanine. Retinas were incubated with $75 \mu \mathrm{M} \mathrm{U}-{ }^{14} \mathrm{C}$ alanine in Ringer solution containing $270 \mathrm{~mm} \mathrm{NaCl}(\mathbb{\sigma})$, or $270 \mathrm{~mm}$ choline chloride $(\square)$.

interconversion of ${ }^{15} \mathrm{~N}$-glutamate to ${ }^{15} \mathrm{~N}$-proline and possibly to ${ }^{15} \mathrm{~N}$-aspartate should be more evident than that appearing in the lower part of Table 2. Such experiments, however, are out of the scope of the present study.

The enzyme that catalyzes the transamination of pyruvate to alanine is ALAT. We measured an activity in drone retina of $538 \mathrm{mU} / \mathrm{mg}$ prot $( \pm 32 \mathrm{SEM}, N=6)$. About $77.5 \%$ of this activity was recovered in the cytoplasmic subcellular fraction (Veuthey et al., 1994). The mitochondrial and the microsomal fractions contained $17 \%$ and $9 \%$ of the total cellular content, respectively.

Cellular site of alanine transamination. Retinas were dissociated to their cellular constituents, glial cells and clusters of photoreceptors, which can easily be identified under the microscope (see Fig. 7 $A, B$ ). Examination of photoreceptors under the electron microscope showed that the clusters were completely stripped off from their glial envelope (Fig. $8 B$ ). Even the finlike glial processes that normally fill the clefts between adjacent photoreceptors were removed by the trituration (Fig. $8 \mathrm{C}$ ). Clusters were tested for viability by pulling them into a close-fitting suction pipette and measuring the light-induced transmembrane current. Light flashes caused changes in current (Fig. 7G), indicating that at least some photoreceptors were preserved. We made purified suspensions of each cell type by collecting, with a suction micropipette, either photoreceptors or glial cells (about 250 clusters $/ \mathrm{hr}$ ). The cell collection time did not exceed $30 \mathrm{~min}$. Usually, two or three retinal slices yielded a sufficient amount of cells for ALAT measurement. When the measurement was made in mixed suspensions of cells immediately following the dissociation procedure, the ALAT activity was close to that found in intact slices, namely, $454 \mathrm{mU} / \mathrm{mg} \cdot \operatorname{protein}( \pm 10.9 \mathrm{SEM}$, $N=4$ ). In purified suspensions the activity was lower: $280 \mathrm{mU} /$ $\mathrm{mg} \cdot$ protein in the glial cells and $240 \mathrm{mU} / \mathrm{mg} \cdot$ protein in the photoreceptors. The isolation procedure led to a loss of ALAT activity, possibly because squeezing of cells during suction partly
Table 2. Stable isotopic enrichment measured by GC-MS analysis after derivatization

\begin{tabular}{lccc} 
& Alanine & Proline & Glutamate \\
\hline Ions & & & \\
$(\mathrm{M}-117)^{+}$ & $117 / 116$ & $143 / 142$ & $247 / 246$ \\
$\left(\mathrm{M}-\mathrm{CH}_{3}\right)$ & $219 / 218$ & $245 / 244$ & $349 / 348$ \\
TMS-derived amino acids & & & \\
Theoretical (calculated) & 19.60 & 21.80 & 30.30 \\
Uncnriched standards & 21.50 & 22.50 & 29.50 \\
Isolated peaks & 30.10 & 23.10 & 53.60 \\
Excess labeling (\%) & 7.9 & 0.6 & 19.4
\end{tabular}

$\mathrm{M}$ was the characteristic fragment ion in the trimethylsilyl (TMS) amino acid electron impact spectra containing the amino group of the molecule. "Ions" refers to the characteristic ions of TMS-amino acids used for calculation of the isotopic enrichment. "TMS-derived amino acids" refers to isotopic ratio (\%) of ions (M$\mathrm{CH}_{3}$ ).

permeabilized the cells, causing some loss of cytoplasm. If we assume that the loss of activity we found was similar in the two kinds of cell, then the results show that the activities were similar.

\section{The metabolic effects of light stimulation}

Figure 9 shows that light flashes evoked a biphasic increase of $\mathrm{QO}_{2}$ : a peak of about $80 \mu \mathrm{l} \mathrm{O} \cdot \mathrm{gm}^{-1} \cdot \mathrm{min}^{-1}$ was followed by a steady state plateau of about $65 \mu \mathrm{O}_{2} \cdot \mathrm{gm}^{-1} \cdot \mathrm{min}^{-1}$ (see also Tsacopoulos and Poitry, 1982). With continuous light (left trace), the amplitude of the transient phase was higher but the plateau phase was markedly lower (Fig. 9). This is probably due to a strong light adaptation. Hence, in order to induce maximum metabolic effect we used stimulation with flashes. As shown in Figure $2 A$, a long-lasting stimulation with light flashes caused a significant decrease in glycogen content. After $2 \mathrm{hr}$ of stimulation in the absence of added substrate, glycogen decreased significantly (about $14 \mathrm{mg} / \mathrm{gm} \cdot$ tissue). However, this decrease is less than that predicted if only glycogen had been used to sustain $\mathrm{QO}_{2}$ (Fig. 2A). Repetitive stimulation for $30 \mathrm{~min}$ did not modify trehalose content (not shown). The same stimulation induced only a $30 \%$ increase of ${ }^{14} \mathrm{CO}_{2}$ production from ${ }^{14} \mathrm{C}$ glucose.

\section{The effects of light stimulation on amino acid metabolism}

There was a clear and consistent effect of photostimulation on the level of several amino acids. As shown in the histogram of Figure $10 A$, the greatest effects were a $51 \%(P=0.001)$ decrease in the concentration of proline and $48 \%(P \leq 0.005)$ decrease of glutamate. There was a concomitant $56.8 \%(P \leq 0.001)$ increase in the concentration of alanine. The small increase of aspartate and glutamine was not statistically significant. The amino acids that were labeled after incubation are shown in Figure $10 B$ and, on expanded ordinate scale, in Figure $10 C$. Light caused an increase in labeling of glutamine and a decrease of ${ }^{14} \mathrm{C}$-glutamate; on the contrary, the pool size of ${ }^{14} \mathrm{C}$-alanine was not significantly affected by light stimulation. It appears that photostimulation increases both the uptake and the utilization of ${ }^{14} \mathrm{C}$-alanine. The utilization was undoubtedly increased because during repetitive stimulation the ${ }^{14} \mathrm{CO}_{2}$ production from $\mathrm{U}-{ }^{14} \mathrm{C}$-alanine increases by more than $60 \%$ (average from five slices).

The effect of light on proline shown in Figure 10 is of particular 

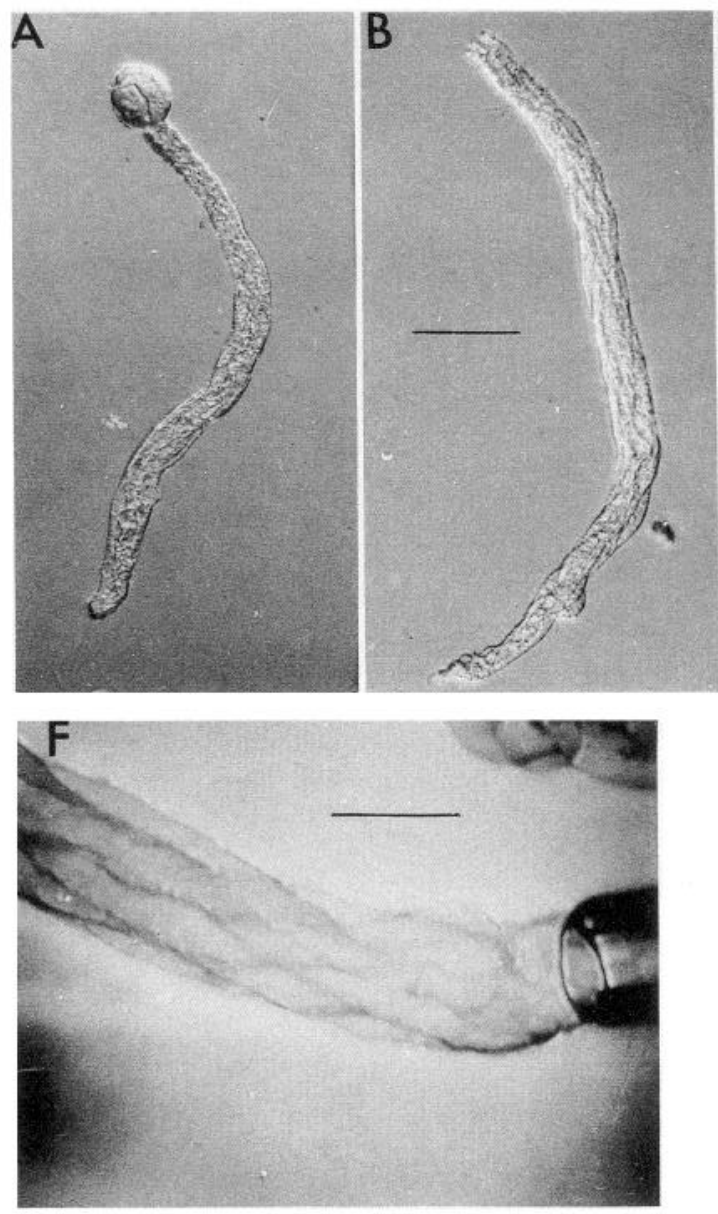
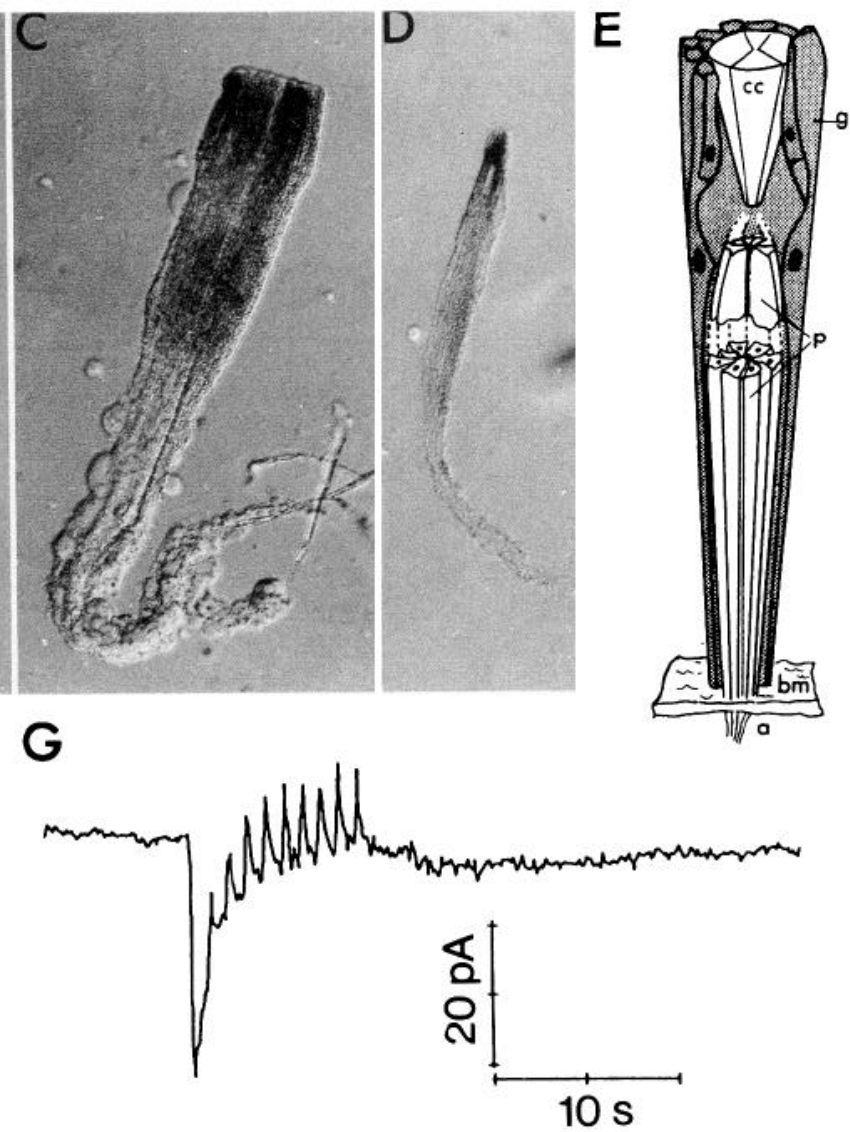

SM

Figure 7. $A-D$, Isolated clusters of photoreceptor cells $(A$ and $B)$ and glial cells $(C$ and $D)$ from the honeybee drone retina. Both are the cellular constituents of one ommatidium schematically presented $(E)$. Scale bar, $100 \mu \mathrm{m}$. The cluster in $A$ still has its lens attached (labeled $c c$ in $E$ ). In such cases the cluster was not collected for enzymatic measurements. Each ommatidium is made of about 25 glial cells ( $g$ in $E$ ), which envelop the six large photoreceptors constituting the cluster $(p$ in $E$ ). In $C$ almost the entire glial group of one ommatidium was isolated. Glial cells remained tightly attached mainly at the proximal (lens) side, but without the photoreceptors and the lens. This can easily be verified under the microscope during the cell collection procedure. Occasionally, individual glial cells or smaller clusters composed of two or three glial cells, as in $D$, were also collected for enzymatic analysis. As shown in $E$, only the axons $(a)$ of the photoreceptors cross the basal membrane $(b m)$ and make synapses in the optic lobe (not shown). These axons were in part sectioned during the isolation procedure. $F$, A photoreceptor cluster is sucked into a tightly fitting recording pipette. Scale bar, $25 \mu \mathrm{m}$. $G$, Light-induced currents were recorded (in response to $40 \mathrm{msec}$ flashes of white light. $S M$, stimulus monitor. The cluster in $F$ was photographed on the video monitor on which the image was projected by means of an infrared video camera. It is conspicuous that the cluster comprises a group of tightly packed individual photoreceptors that twist with respect to the longitudinal axis. Because the light spot illuminated only a small part of the cluster (see Materials and Methods), it is difficult to interpret rigorously the direction of the lightinduced currents underlying the responses shown in $G$. The same response was elicited several times and in several clusters.

interest because this amino acid has been considered as a mitochondrial fuel in flight muscles of insects, and honeybees in particular (see Barker and Lehner, 1972), and its concentration in the drone retina is very high (Table 1). As shown in Table 1 , the concentration of proline in the retina decreases significantly during superfusion or bathing in substrate-free Ringer solution. After $2 \mathrm{hr}$ the decrease was about $80 \%$. Incubation of retinal slices with ${ }^{14} \mathrm{C}$-proline $(375 \mu \mathrm{M})$ for $60 \mathrm{~min}$ led to the intracellular accumulation of the equivalent of $1.2 \mathrm{~mm}$ of ${ }^{14} \mathrm{C}$ proline. This corresponds to a small specific radioactivity (see Table 1). The chromatogram presented in Figure $4 C$ shows that the amino acids labeled from ${ }^{14} \mathrm{C}$-proline were glutamate, and to a lesser degree glutamine. The estimated specific radioactivity of glutamate under these conditions was $2.81 \%( \pm 0.019$ SEM, $N=5$ ), about six times higher than after incubation with $\mathrm{U}-{ }^{14} \mathrm{C}$ glucose. The incubation of retinas in Ringer solution carrying $260 \mu \mathrm{M}$ of ${ }^{14} \mathrm{C}$-proline as sole added substrate produced ${ }^{14} \mathrm{CO}_{2}$. The rate of ${ }^{14} \mathrm{CO}_{2}$ appearance increased over the first period of the incubation and after about $80 \mathrm{~min}$ in darkness reached a maximal steady state rate of $165 \mathrm{nmol}( \pm 6.2 \mathrm{SEM}, N=6)$ of ${ }^{14} \mathrm{CO}_{2}$ ( $\mathrm{ml}$ of retina $)^{-1} \cdot \mathrm{min}^{-1}$. This steady state repetitive stimulation of the retina for $20 \mathrm{~min}$ induced a further $60 \%$ rise in the rate of ${ }^{14} \mathrm{CO}_{2}$ production (five retinas). Hence, ${ }^{14} \mathrm{C}$-proline is oxidized by the mitochondria of the drone retina.

\section{Discussion}

Our work supports the following model of metabolic interactions between glial and photoreceptors cells in the bee retina (Fig. 11). Glucose is phosphorylated to glucose-6P in the glial cells (Tsacopoulos et al., 1988; Brazitikos and Tsacopoulos, 1991 ) and is subsequently incorporated into trehalose and glycogen (Fig. 1; Evêquoz-Mercier and Tsacopoulos, 1991), as well as metabolized to pyruvate, which in turn is transaminated to alanine. Our model proposes that alanine formation occurs in the glial cell. This is supported by the following results. Glial 


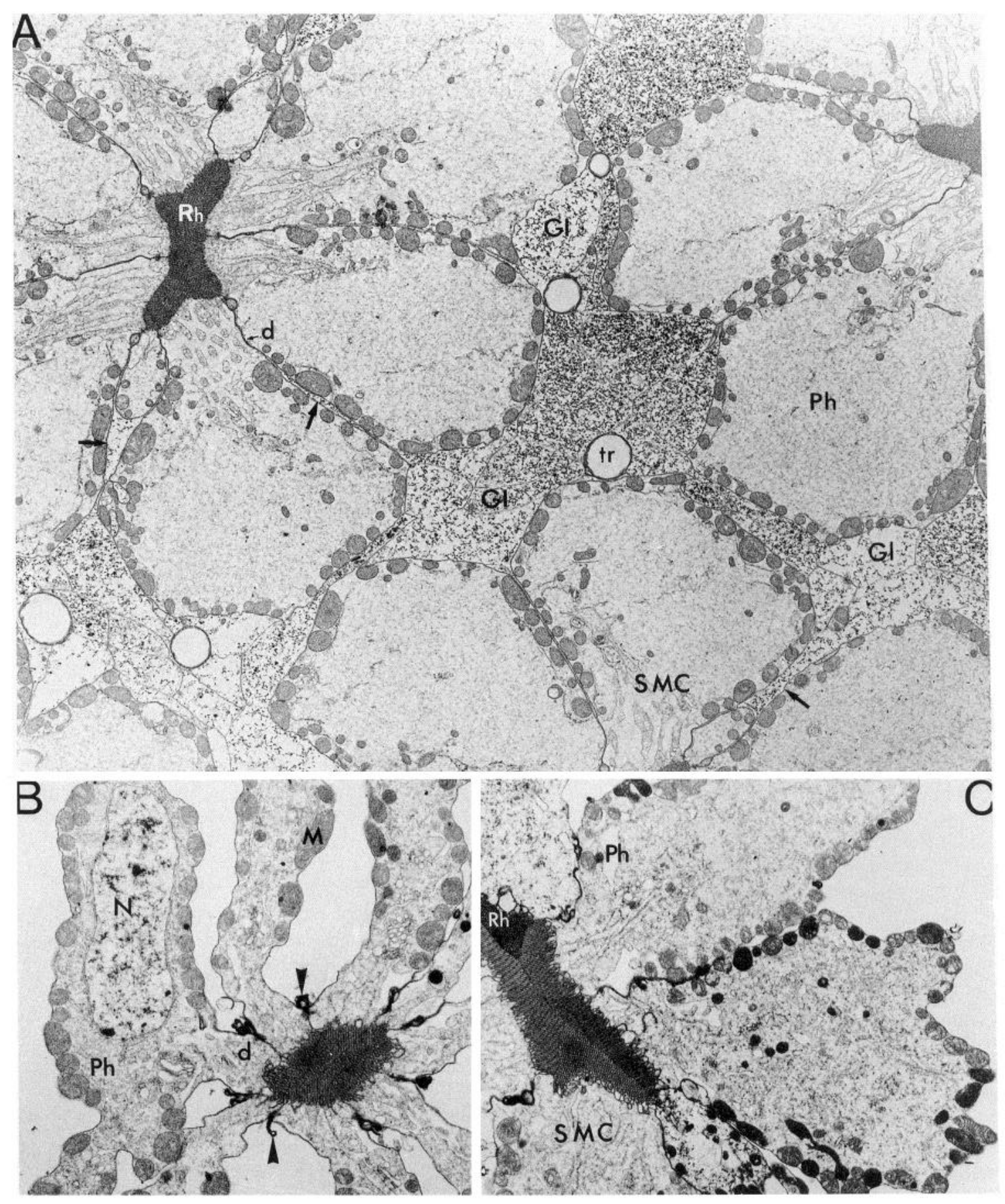

Figure 8. A, Electron micrograph showing a cross section through part of an intact drone retina, perpendicular to the long axes of photoreceptor cells. Each photoreceptor $(P h)$ contributes microvilli to the rhabdom $(R h)$, where rhodopsin is located. The photoreceptors contain many mitochondria and well-developed vacuole-like submicrovillar cisternae (SMC), a type of endoplasmic reticulum, having a high Ca content (Baumann et al., 1991). The surrounding glial cells $(\mathrm{Gl})$ contain almost no mitochondria and send fin-like processes (arrows) between the photoreceptors almost to the rhabdom. Tracheoles ( $t r)$ run parallel to the axes of the photoreceptors. This section is near the middle of the ommatidia (see Fig. $7 E$ ) and photoreceptors occupy more of the space. The photoreceptor is about $15 \mu \mathrm{m}$ across. $B$ and $C$, Micrographs of isolated photoreceptor clusters (retinulae). The section in $B$ is proximal to the crystalline cone (see Fig. $7 E$ ), since the nucleus $(N)$ is present and the rhabdom is small (see details in Perrelet, 1970). In this part of the retina glial cells occupy more space than photoreceptors. Glial cells are completely removed by the isolation procedure; however, some membrane fragments of glial cells remain attached close to the site where photoreceptors make contacts (arrowheads). The section in $C$ is distal to that in $B$. The photoreceptors are larger, and no glial cells are present. Even the fin-like processes have been removed.

cells contain very few mitochondria (see Fig. 8 and Dimitracos and Tsacopoulos, 1985) and therefore glycolysis in these cells probably proceeds anaerobically, particularly during photostimulation, which increases considerably their rate of glucose consumption (Brazitikos and Tsacopoulos, 1991). The bee retina, like the flight muscle (Sacktor, 1975), does not produce lactate (Fig. 1). Hence, to sustain the redox potential and to reoxidize NADH to $\mathrm{NAD}^{+}$, which are necessary to maintain 


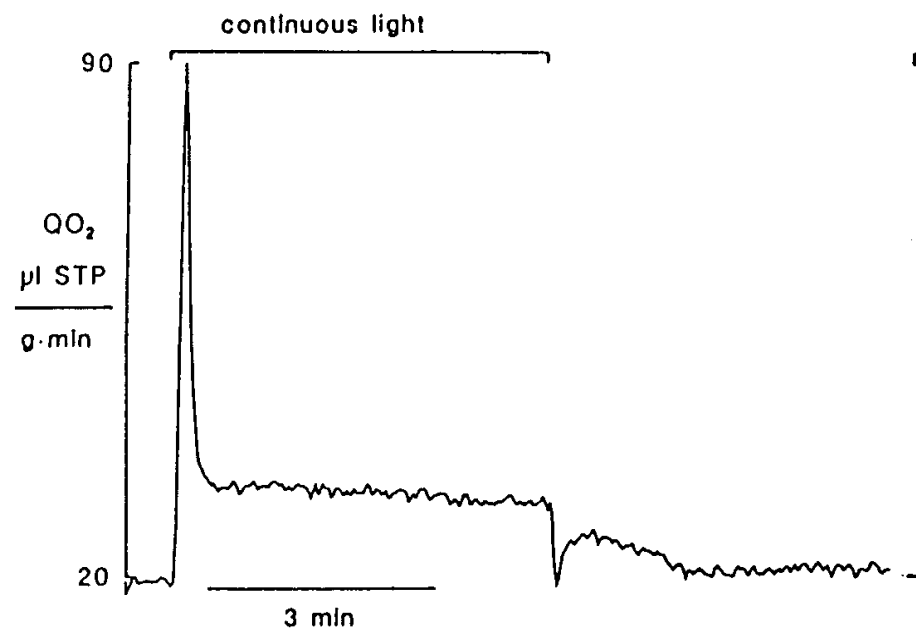

light llashes

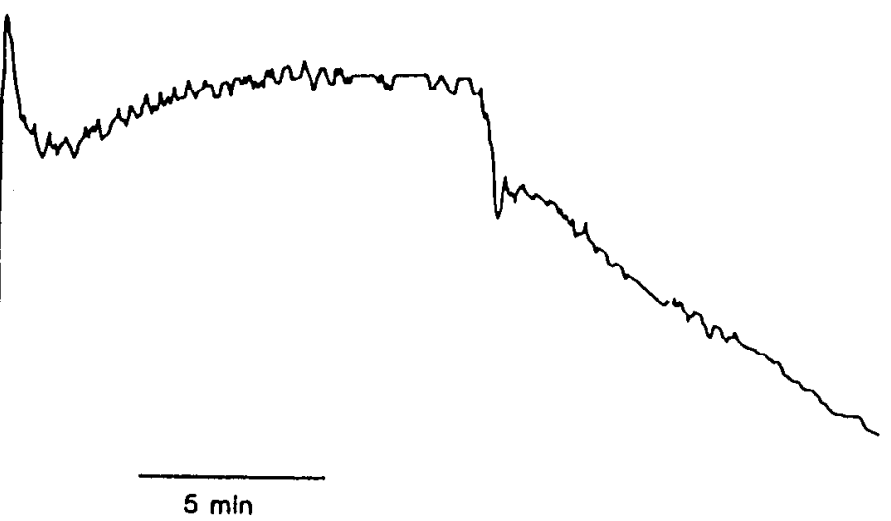

Figure 9. The effect of light on oxygen consumption $\left(\mathrm{QO}_{2}\right)$ by retinal slice. The induced changes in $\mathrm{PO}_{2}$ were measured with two microelectrodes, one at the superfused surface of the slice and one $150 \mu \mathrm{m}$ deep in the tissue. The thickness of the slice was $\sim 300 \mu \mathrm{m}$. QO, was calculated from $\mathrm{PO}_{2}$ using fast Fourier transforms as described in Tsacopoulos and Poitry (1982). The retina was superfused in the absence of substrate and was dark adapted for $30 \mathrm{~min}$. It was then stimulated, first with continuous light (left), and, following $30 \mathrm{~min}$ in the dark, with successive $30 \mathrm{msec}$ flashes of white light (see Jones and Tsacopoulos, 1987) presented to the retina every 5 sec. STP is "standard temperature and pressure."

the glycolytic flux in glial cells, pyruvate is transaminated to alanine through the action of ALAT and NADH is converted to $\mathrm{NAD}^{+}$by further amination of the produced $\alpha$-ketoglutarate through the reaction of glutamate dehydrogenase (GDH) (Fig. 11). Also, ALAT and GDH could function in tandem to directly oxidize NADH and fix ammonia according to the equation demonstrated in vitro by Fahien et al. (1971):

pyruvate $+\mathrm{NADH}+\mathrm{NH}_{3} \underset{\text { GDH }}{\stackrel{\text { ALAT }}{\longrightarrow}}$ alanine $+\mathrm{NAD}^{+}+\mathrm{H}_{2} \mathrm{O}$

However, since our experiments with ${ }^{15} \mathrm{~N}$-glutamate showed that glutamate is a nitrogen donor for the transamination of pyruvate to alanine, the pyruvate/glutamate transamination is included in the model (Fig. 11).

In support of this tandem reaction, we observed that alanine synthesis depends on the integrity of glycolysis, since the glyceraldehyde-3-phosphate dehydrogenase inhibitor IAA suppressed the formation of ${ }^{14} \mathrm{C}$-alanine from $\mathrm{U}-{ }^{14} \mathrm{C}$-glucose and reduced the pool size of alanine by more than $50 \%$. Under normal superfusion, alanine was the only amino acid whose intracellular pool was maintained stable or even increased in the absence of added metabolic substrate (Table 1). The glycogen reserve was probably used under this condition (Fig. 2).

The alanine synthesized in the glia is released into the extracellular space and is then transported into photoreceptors (Fig. 11). Consistent with this hypothesis are the absence of specialized contacts for the passage of molecules between the membranes of glial and photoreceptors cells (Perrelet, 1970) and our results showing an uptake of ${ }^{14} \mathrm{C}$-alanine by a $\mathrm{Na}^{+}$-dependent membrane transport mechanism like in mammalian cells (see Christensen, 1990).

Following its entry in the photoreceptor, alanine is transaminated to pyruvate, the acetyl residue of which in turn enters the Krebs cycle in the mitochondria (Fig. 11). Three lines of experimental evidence support this notion: first, the transformation of ${ }^{14} \mathrm{C}$-alanine to glutamate, aspartate, and $\mathrm{CO}_{2}$; second, the presence of ALAT in isolated photoreceptors (possibly an isoform of glial ALAT operating with different $\mathrm{p} K$; see Ruscak et al., 1982) completely stripped of their glial envelope (Fig.
$8 B$ ); and third, photostimulation induced an increase in the consumption of ${ }^{14} \mathrm{C}$-alanine in the photoreceptor since ${ }^{14} \mathrm{CO}_{2}$ production increased by more than $60 \%$.

Our model proposes proline as a second substrate for the Krebs cycle (Fig. 11). The following three sets of experimental data are consistent with this view: proline produced glutamate, which in turn enters the Krebs cycle as $\alpha$-ketoglutarate (Fig. 4). Light stimulation caused a strong decrease of both proline and of glutamate. Using isolated mitochondria from the drone retina we observed that proline in the presence of pyruvate and absence of ADP and $\alpha$-glycerol-phosphate sharply accelerated $\mathrm{O}_{2}$ consumption (M. Prentki and M. Tsacopoulos, unpublished observations). Finally, the production of ${ }^{14} \mathrm{CO}_{2}$ from ${ }^{14} \mathrm{C}$-proline was similar to that from ${ }^{14} \mathrm{C}$-alanine and light stimulation caused a $60 \%$ rise in ${ }^{14} \mathrm{CO}_{2}$ production from ${ }^{14} \mathrm{C}$-proline or ${ }^{14} \mathrm{C}$-alanine. Sacktor and Childress (1967) found that the mitochondrial membrane of flight muscle of bumble hees is permeable to proline but not to glutamate. This may also be the case in the honeybee retina. Indeed, light stimulation induces in invertebrate photoreceptors a massive $\mathrm{Ca}^{2+}$ rise and simultaneously a $\Delta \mathrm{QO}_{2}$ (Levy and Fein, 1985; Fein and Tsacopoulos, 1988). This occurs by activation of mitochondrial enzymes, accelerating, in turn, the rate of utilization of glutamate made from proline inside the mitochondria. Since the drone retina does not synthesize proline from glycogen (bees take proline from pollen; Auclair and Jamieson, 1948), the pool size of proline (and also of glutamate) decreased by $10 \mathrm{~mm}$ in the stimulated superfused retina (Fig. 10). The use of proline in the Krebs cycle appears necessary in view of the following results: during photostimulation, the $\mathrm{QO}_{2}$ of the retina in steady state is on average $62 \mu \mathrm{l}$ $\mathrm{O}_{2} / \mathrm{cm}^{3} \cdot \min$. This corresponds to approximately the production of $33.2 \mathrm{mmol}$ of ATP per liter of photoreceptor per minute, whose major part is used for a fundamental function: pumping $\mathrm{Na}^{+}$out of the photoreceptor (Fig. 9; Tsacopoulos and Poitry, 1982; Tsacopoulos et al., 1983; Coles and Orkand, 1985). For such a large production of ATP, the supply of acetyl-CoA to the Krebs cycle from pyruvate would not be sufficient and Krebs cycle intermediates, although used catalytically in the cycle, may become limiting upon light stimulation unless they rise. Therefore, it appears likely that Krebs cycle intermediates must be 
increased in an anaplerotic reaction catalyzed by GDH during photostimulation. However, we do not exclude other anaplerotic reactions such as increased flux through pyruvate carboxylase yielding oxaloacetate. However, since light stimulation did not induce a decrease in the pool size of aspartate, we did not explore this function in detail.

The strong effect of light stimulation on proline utilization (10 mm decrease) implies high production of $\mathrm{NH}_{3}$ (Fig. 11). The reaction contributing to $\mathrm{NH}_{3}$ fixation in mammalian nervous tissues is glutamine formation that uses ATP. In our model alanine formation also fixes $\mathrm{NH}_{3}$ (see also Eq. 1). Our results showed that this reaction exceeds glutamine formation. The functional implications of this could be that in this way the mitochondria-poor drone glial cells preserve their ATP pool, and as shown in the Results increase their alanine pool size upon photostimulation. This increase is interpreted as follows. The model (Fig. 11) proposes a glial site for alanine biosynthesis and a photoreceptor site for its utilization, implying the existence of two pools of this amino acid. Indeed, using a one compartment model of first-order reaction kinetics (Rodiguin and Rodiguina, 1964) and some reasonable assumptions, namely, that the concentrations of reactants are in steady state and that the glycolytic flux is just sufficient to sustain the oxidative metabolism, we calculated that the expected concentration of ${ }^{14} \mathrm{C}$-alanine after a $60 \mathrm{~min}$ incubation with ${ }^{14} \mathrm{C}$-glucose should be about $3.7 \mathrm{~mm}$. This is about three times more than found experimentally, thus supporting the hypothesis of two separate pools of alanine. Consequently, the result showing an increase of the pool size of alanine upon photostimulation indicates that synthesis of alanine in the glia by stimulated glycolysis exceeds the utilization of the photoreceptor pool. This excess in synthesis already described by previous authors in a variety of mammalian and insects cells (Treherne, 1960; Sacktor and WormserShavit, 1966; Shimada et al., 1973; Chapman et al., 1977; Sanders and Kon, 1992; Yudkoff et al., 1992) is plausible according to our model for $\mathrm{NH}_{3}$ homeostasis. It is of interest then that Coles et al. (1988) found a light-induced transient alkalinization in the extracellular space of the drone retina. Also, photostimulation causes a transient increase in the extracellular $\mathrm{NH}_{3}$ concentration of about $100 \mu \mathrm{M}$, indicating traffic of $\mathrm{NH}_{3}$ between photoreceptor and glial cells (J. A. Coles, personal communication).

The principal information emerging from this article is that in a nervous system with a crystal-like structure, glial cells transform glucose to alaninc, which in turn fucls the photoreceptor neurons. We suggest that this finding is of general neurobiological interest. Previous authors paid little attention as to the functional significance of alanine formation in the brain (see Erecinska and Silver, 1990). However, Yudkoff et al. (1986) found in cultured astrocytes an important flux of nitrogen from glutamate to alanine corresponding to a net alanine synthesis. They proposed that alanine released from astrocytes is utilized by neurons to synthesize glutamate (Yudkoffet al., 1986), whereas we would suggest that in higher eukaryotes alanine may actually be the substrate that feeds the neurons to sustain their energy needs. In this context it is worth mentioning that the pool size of free alanine in the rat brain slices is $0.8 \mathrm{~mm}$ (about 15-fold lower than in the bee retina), increasing to about $6 \mathrm{~mm}$ after 2 hr incubation with $10 \mathrm{~mm}$ glucose (Cory and Rose, 1969). On the contrary, the pool size of alanine in octopus optic lobe is closer to that found in the bee and it is relatively little altered after incubation with glucose. Hence, in a variety of nervous tissues at least part of glucose is transformed to alanine.
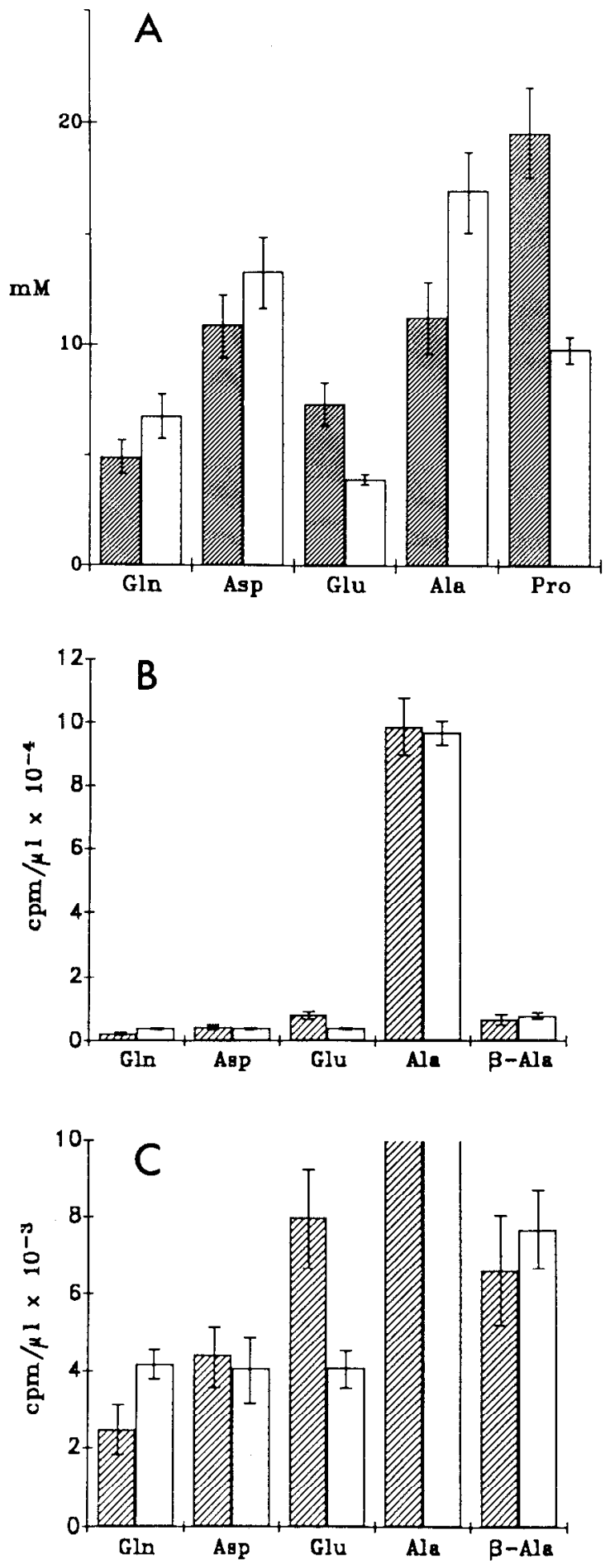

Figure 10. Effect of repetitive light stimulation on the cellular content of various amino acids. $A$, Total concentrations. The hatched and open bars represent values measured in dark-adapted and light-stimulated retinas, respectively. Each value is the mean \pm SEM of at least five retinal slices. $B$, Labeling after incubation in ${ }^{14} \mathrm{C}$-alanine. Proline was not labeled from ${ }^{14} \mathrm{C}$-alanine and therefore is not included in this graph. The graph in $C$ is plotted with an expanded vertical scale as compared to $B$. In each homogenate made from one retinal slice the total concentration and the labeled fractions were measured.

In conclusion, the results reported here strongly support a nutritive function for glia and that in the drone retina metabolic coupling between glial and photoreceptor cells is mediated by alanine. Further work is needed to establish the validity of the 
Figure 11. Model of metabolic interaction between a glial cell and a photoreceptor. The enzyme alanine aminotransferase $(A L A T)$ catalyzes a readily reversible reaction. The extracellular space $(E S)$ is drawn disproportionately large.

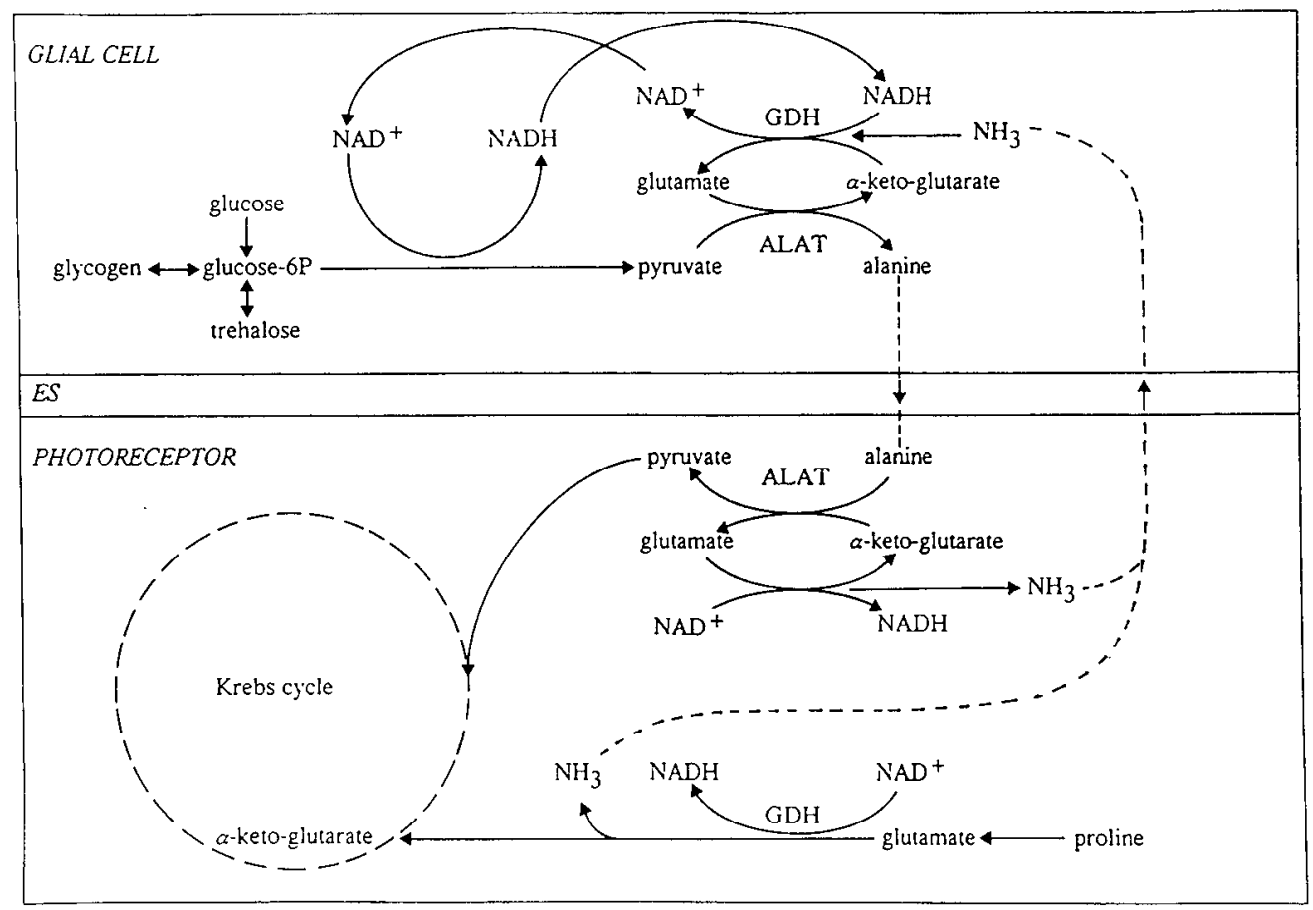

drone retina model and it would be of interest to determine whether other nervous tissues use alanine for their metabolic interactions.

\section{References}

Auclair JL, Jamieson CA (1948) A qualitative analysis of amino acids in pollen collected by bees. Sciences 108:357-358.

Barker RJ, Lehner Y (1972) Free amino acids in thoraces of flown honey bees, Apis mellifera L. (Hymenoptera: Apidae). Comp Biochem Physiol 43B:163-169.

Barres BA (1991) New roles for glia. J Neurosci 11:3685-3694.

Baumann O (1992) Submembrane cytoskeleton of pigmented glial cells, primary pigment cells and crystalline cone cells in the honeybee compound eye. Cell Tissue Res 270:353-363.

Baumann O, Walz B, Somlyo AV, Somlyo AP (1991) Electron probe microanalysis of calcium release and magnesium uptake by endoplasmic reticulum in bee photoreceptors. Proc Natl Acad Sci USA 88:741-744.

Brazitikos PD, Tsacopoulos M (1991) Metabolic signaling between photoreceptors and glial cells in the retina of the drone (Apis mellifera). Brain Res 567:33-41.

Chapman AG, Meldrum BS, Siesjö BK (1977) Cerebral metabolic changes during prolonged epileptic seizures in rats. J Neurochem 28: 1025-1035.

Christensen HN (1990) Role of amino acid transport and countertransport in nutrition and metabolism. Physiol Rev 70:43-77.

Coles JA, Orkand RK (1985) Changes in sodium activity during light stimulation in photoreceptors, glia and extracellular space in drone retina. J Physiol (Lond) 362:415-435.

Coles JA, Giovannini P, Thomas RC (1988) Changes in extracellular $\mathrm{pH}$ induced by light stimulation in slices of honeybee drone retina. J Physiol (Lond) 398:59P.

Cornwall CM, Fein A, Mac Nichol EF Jr (1983) Spatial localization of bleaching adaptation in isolated vertebrate rod photoreceptors. Proc Natl Acad Sci USA 80:2785-2788.

Cory HT, Rose SPR (1969) Glucose and amino acid metabolism in octopus optic and vertical lobes in vitro. J Neurochem 16:979-988.

Dimitracos SA, Tsacopoulos M (1985) The recovery from a transient inhibition of the oxidative metabolism of the photoreceptors of the drone (Apis mellifera \$). J Exp Biol 119:165-181.

Erecinska M. Silver IA (1990) Metabolism and role of glutamate in mammalian brain. Prog Neurobiol 35:245-296.

Erecinska M, Zaleska MM, Nissim I, Nelson D, Dagani F, Yudkoff
M (1988) Glucose and synaptosomal glutamate metabolism: studies with ${ }^{5} \mathrm{~N}$-glutamate. J Neurochem 51:892-902.

Evêquoz V, Stadelmann A, Tsacopoulos M (1983) The effect of light on glycogen turnover in the retina of the intact honeybee drone (Apis mellifera). J Comp Physiol 150:69-75.

Evêquoz-Mercier V, Tsacopoulos M (1991) The light-induced increase of carbohydrate metabolism in glial cells of the honcybce retina is not mediated by $\mathrm{K}^{+}$movement nor by cAMP. J Gen Physiol 98: $497-515$.

Fahien LA, Lin-Yu YH, Smith SE, Happy JM (1971) Interactions between glutamate dehydrogenase, transaminases and ketoacids. J Biol Chem 246:7241-7249.

Favre E, Pugeaud P, Péringer P (1990) Automated HPLC monitoring of glucose, glutamine, lactate and alanine on suspended mammalian cell reactors. Biotechnol Tech 4:315-320.

Fein A, Tsacopoulos M (1988) Activation of mitochondrial oxidative metabolism by calcium ions in Limulus ventral photoreceptor. Nature $331: 437-440$.

Fierabracci V, Masiello P, Novelli M, Bergamini E (1991) Application of amino acid analysis by high-performance liquid chromatography with phenyl isothiocyanate derivatization to the rapid determination of free amino acids in biological samples. J Chromatogr 570:285291.

Golgi C (1903) Sulla fina anatomia degli organi centrali del sisterna nervoso. In: Opera omnia, Vol II, p 460. Milano: Hoepli.

Hertz L, Yu ACH, Potter RL, Fisher TE, Schousboe A (1983)Metabolic fluxes from glutamate and towards glutamate in neurons and astrocytes in primary cultures. In: Glutamine, glutamate and GABA in the central nervous system (Hertz L, Kvamme E, McGeer EG, Schousboe A, eds), pp 327-342. New York: Liss.

Jones GJ, Tsacopoulos M (1987) The response to monochromatic light flashes of the oxygen consumption of honeybee drone photoreceptors. J Gen Physiol 89:791-813.

Kuffler SW, Nicholls JG (1976) From neuron to brain. Sunderland, MA: Sinauer.

Lajtha AL, Maker HS, Clarke DD (1981) Metabolism and transport of carbohydrates and amino acids. In: Basic neurochemistry (Siegel GJ, Albers RW, Agranoff BW, Katzman R, eds), pp 329-353. Boston: Little, Brown.

Levy S, Fein A (1985) Relationship between light sensitivity and intracellular free $\mathrm{Ca}$ concentration in Limulus ventral photoreceptors. J Gen Physiol 85:805-841.

Lowry OH, Passonneau JV (1972) A flexible system of enzymatic analysis, pp 71-77, 179-182. London: Academic.

Lowry OH, Passonneau JV, Hasselberger FX, Schulz DW (1964) Effect 
of ischemia on known substrates and cofactors of glycolytic pathway in brain. J Biol Chem 239:18-30.

Nahorski SR, Rogers KJ (1972) An enzymatic fluorometric micromethod for determination of glycogen. Anal Biochem 49:492-497.

Perrelet A (1970) The fine structure of the retina of the honey-bee drone. Z Zellforsch Mikrosk Anat 108:530-562.

Poitry-Yamate CL, Tsacopoulos M (1992) Glucose metabolism in freshly isolated Müller glial cells from a mammalian retina. J Comp Neurol 320:257-266.

Rodiguin NM, Rodiguina EN (1964) Consecutive chemical reactions. Mathematical analysis and development. Princeton, NJ: Van Nostrand.

Rosenblatt J, Chinkes D, Wolfe M, Wolfe RR (1992) Stable isotope tracer analysis by GC-MS, including quantification of isotopomer effects. Aml J Physiol 263:E584-E596.

Ruscak M, Orlicky J, Zubor V, Hager H (1982) Alanine aminotransferase in bovine brain: purification and properties. J Neurochem 39: $210-216$.

Sacktor B (1975) Biochemistry of insect flight. In: Insect biochemistry and function (Candy DJ, Kilby BA, eds), pp 1-88. London: Chapman and Hall.

Sacktor B, Childress CC (1967) Metabolism of proline in insect flight muscle and its significance in stimulating the oxidation of pyruvate. Arch Biochem Biophys 120:583-588.

Sacktor B, Wormser-Shavit E (1966) Regulation of metabolism in working muscle in vivo. I. Concentrations of some glycolytic, tricarboxylic acid cycle, and amino acid intermediates in insect flight muscle during flight. J Biol Chem 241:624-631.

Sanders MM, Kon C (1992) Glutamine and glutamate metabolism in normal and heat shock conditions in Drosophila Kc cells: conditions supporting glutamine synthesis maximize heat shock polypeptide expression. J Cell Physiol 150:620-631

Shimada M, Kihara T, Kurimoto K, Watanabe M (1973) Incorporation of ${ }^{14} \mathrm{C}$ from $\left[\mathrm{U}-{ }^{14} \mathrm{C}\right]$ glucose into free amino acids in mouse brain loci in vivo under normal conditions. J Neurochem 20:13371344.
Smith PK, Krohn RI, Hermanson GT, Mallia AK, Gartner FH, Provenzano MD, Fujimoto EK, Goeke NM, Olson BJ, Klenk DC(1985) Measurement of protein using bicinchoninic acid. Anal Biochem 150: $76-85$.

Sorg O, Magistretti PJ (1992) Vasoactive intestinal peptide and noradrenaline exert long-term control on glycogen levels in astrocytes: blockade by protein synthesis inhibition. J Neurosci 12:4923-4931.

Treherne JE (1960) The nutrition of the central nervous system in the cockroach, Periplaneta americana L. J Exp Biol 137:513-533.

Tsacopoulos M, Poitry S (1982) Kinetics of oxygen consumption after a single flash of light in photoreceptors of the drone (Apis mellifera). J Gen Physiol 80:19-55.

Tsacopoulos M, Poitry S, Borsellino A (1981) Diffusion and consumption of oxygen in the superfused retina of the drone (Apis mellifera) in darkness. J Gen Physiol 77:601-628.

Tsacopoulos M, Orkand RK, Coles JA, Levy S, Poitry S (1983)Oxygen uptake occurs faster than sodium pumping in bee retina after a light flash. Nature 301:604-606.

Tsacopoulos M, Coles JA, Van de Werve G (1987) The supply of metabolic substrate from glia to photoreceptors in the retina of the honeybee drone. J Physiol (Paris) 82:279-287.

Tsacopoulos M, Evêquoz-Mercier V, Perrottet P, Buchner E (1988) Honeybee retinal glial cells transform glucose and supply the neurons with metabolic substrate. Proc Natl Acad Sci USA 85:8727-8731.

Turnell DC, Cooper JDH (1982) Rapid assay for amino acids in serum or urine by pre-column derivatization and reversed-phase liquid chromatography. Clin Chem 28:527-531

Veuthey AL, Tsacopoulos M, Millan de Ruiz L, Perrottet P (1994) J Neurochem, in press.

Yudkoff M, Nissim I, Hummeler K, Medow M, Pleasure D (1986) Utilization of $\left[{ }^{15} \mathrm{~N}\right]$ glutamate by cultured astrocytes. Biochem J 234: 185-192.

Yudkoff M, Nissim I, Hertz L, Pleasure D, Erecinska M (1992) Nitrogen metabolism: neuronal-astroglial relationships. In: Progress in brain research, Vol 94 (Yu ACH, Hertz L, Norenberg MD, Sykova E, Waxman SG, eds), pp 213-224. Amsterdam: Elsevier. 